\title{
Comments
}

\section{THE CIVIL RIGHTS ACTS AND MR. MONROE}

In the years immediately following the close of the Civil War, Congress enacted a series of five statutes, called the Civil Rights Acts, ${ }^{1}$ which were designed to clarify and protect the rights of the Negro in his newly acquired status as a freedman. ${ }^{2}$ This statutory scheme met with little enduring success, most of its provisions having been repealed or severely limited by court decision. ${ }^{3}$ Some remnants of significance remain, however, among which are two sections of the act of April 20, $1871,{ }^{4}$ the Third Civil Rights Act. ${ }^{5}$ These two sections, now found in 42 U.S.C. section $1983^{6}$ and 28 U.S.C. section $1343(3),{ }^{7}$ create a cause of action (section 1983) and confer jurisdiction (section 1343(3)) upon the district courts in civil actions brought to redress the deprivation, under color of state law, of rights, privileges, and immunities secured by the Constitution and laws of the Umited States. ${ }^{8}$

During its present term, the Supreme Court for the first time has given an authoritative defimition of the injuries which nnay be redressed im the federal courts under section 1983. In Monroe v. Pape, ${ }^{9}$ a landmark decision, the Court held that

1 Civil Rights Act of 1866, 14 Stat. 27 (1866) ; the Enforcement Act, 16 Stat. 140 (1870); the amendments to the Enforcement Act, 16 Stat. 433 (1871); Civil Rights Act of April 20, 1871, 17 Stat. 13 (1871); Civil Rights Act of March 1, 1875, 18 Stat. 335 (1875).

2 An authoritative discussion of the background and history of the Civil Rights Acts may be found in Gressman, The Unhappy History of Civil Rights Legislation, 50 MICH. L. Rev. 1323 (1952).

3 "It is a matter of well documented history that civil rights legislation passed shortly after the Civil War to combat 'Black Codes,' $\mathrm{Ku}$ Klux Klan activities and general state frustration of Negro rights was, for the most part, strictly construed through a series of cases which all but eradicated the original Congressional intent. In re Slaughter-House Cases, 16 Wall. (83 U.S.) 36, 21 L. Ed. 349; United States v. Cruikshank, 92 U.S. 542, 23 L. Ed. 588; United States v. Harris, 106 U.S. 629, 1 S.Ct. 601, 27 L. Ed. 290; In re Civil Rights Cases, 109 U.S. 3, 3 S.Ct. 18, 27 L. Ed. 835; Baldwin v. Franks, 120 U.S. 678, 7 S.Ct. 763, 32 L.Ed 766; James v. Bowman, 190 U.S. 127,23 S.Ct. 678,47 L. Ed. 979 . These decisions not only narrowly interpreted the rights, privileges, and immunities secured by the Fourteenth Amendment and restricted the protection of these rights to actions of a state, but also declared certain of the Acts unconstitutional." Egan v. City of Aurora, 174 F. Supp. 794, 797 (N.D. Ill. 1959), aff'd, 275 F.2d 377 (7th Cir. 1960).

For a résumé of the legislative and judicial annihilation of the Civil Rights Acts, see Gressman, The Unhappy History of Civil Rights Legislation, 50 MICE. L. REv. 1323 (1952). See also Fraenkel, The Federal Civil Rights Laws, 31 MnvN. L. Rev. 301 (1947); Clark, A Federal Prosecutor Looks at the Civil Rights Statutes, 47 CoLuM. L. REv. 175 (1947).

417 Stat. 13 (1871).

5 Entitled "An Act to enforce the Provisions of the Fourteenth Amendment to the Constitution of the United States, and for other Purposes," the act of April 20, 1871, was popularly known as the "Klu Klux Klan Act" and was "passed by a partisan vote in a highly enflamed atmosphere." Mr. Justice Jackson, speaking for the Court, in Collins v. Hardyman, 341 U.S. 651,657 (1951). The act "was among the last of the reconstruction legislation to be based on the 'conquered province' theory which prevailed in Congress for a period following the Civil War. This statute ... established . . . civil liabilities, together with parallel criminal liabilities." Id. at 656 .

6 REv. STAT. § 1979 (1875), 42 U.S.C. § 1983 (1958).

7 REV. STAT. \& 628 (1875), 28 U.S.C. \$ 1343 (3) (1958).

8 See generally Poole, Statutory Remedies for the Protection of Civil Rights, 32 Ore. L. Rev. 210 (1953); Comment, The Proper Scope of the Civil Rights Acts, 66 HARv. L. REv. 1285 (1953); Comment, The Civil Rights Acts: Emergence of an Adequate Federal Civil Remedy?, 26 Ind. L.J. 361 (1951); Note, 7 BAYLOR L. REv. 224 (1955).

881 S. Ct. 473 (1961). 
a cause of action is stated under section 1983 whenever the plaintiff alleges a denial of due process at the hands of state officials, even though they were acting in violation of state law.

Plaintiffs, eight members of the same family, alleged that a squad of thirteen Chicago policemen, led by Deputy Chief of Detectives Pape, broke into their apartment in the early morning hours, took them from their beds and forced the mother and father to stand naked in the living room, together with the children, while the police ransacked the apartment, dumping drawers, ripping mattress covers, and emptying closets in a search for clues to a recent murder. The police had neither a search warrant nor a warrant for anyone's arrest. Nevertheless, they took Mr. Monroe to police headquarters where they held him incommunicado for ten hours, subjecting him to interrogation and exhibiting him in police lineups. During this period they did not bring him before a magistrate, though several were available, nor did they inform him of his rights or allow him to see an attorney. He was then released without criminal charges having been filed against him. Under state law, the search of the apartment had been illegal, ${ }^{10}$ but Monroe's detention was sanctioned by the Chicago police department as a part of its customary procedures. 11

The plaintiffs brought suit in the district court against the policemen and their employer, the city, alleging a deprivation of their rights to due process and equal protection of the law. Hardly a more perfect set of facts could have existed for bringing suit under section 1983. Yet the district court ${ }^{12}$ and the Court of Appeals for the Seventh Circuit ${ }^{13}$ held that plaintiffs had failed to state a cause of action and directed them to seek redress in the state tribunals. On certiorari, the Supreme Court, speaking through Mr. Justice Douglas, drew heavily upon the legislative history of the Civil Rights Acts in affirming the dismissal of the complaint as to the city and reversing as to the police. The Court placed its reversal on due process grounds, and did not reach the issue of whether plaintiffs had stated a cause of action for a denial of equal protection. The only dissenter was Justice Frankfurter. ${ }^{14}$ Although he could agree with the Court on everything else, he could not agree that the words action "under color of any statute, ordinance, regulation, custom, or usage of any state," as used in section $1983,{ }^{15}$ referred to the illegal acts of state officials.

In the course of its decision the Court cleared away some ninety years of underbrush and brought section 1983 into sharp focus as an instrument for the enforcement of fourteenth amendment rights. But the real significance of the decision lies in its effect upon the jurisdiction of the district courts. Implicit in the Court's opinion is the assumption that the district court had jurisdiction of the Monroes' claim under section 1343(3), as indeed it must have had, since the relevant language of that section is nearly identical witl that construed by the Court. ${ }^{16}$

It would be a mistake, however, to assume that the decision in Monroe was unheralded. Ever simce 1938, the year of Mr. Justice Stone's opinion in Hague v.

$10 \mathrm{Id}$. at 476.

$11 \mathrm{Id}$. at 522-23.

12 Apparently the opinion of the lower court was not reported.

13 Monroe v. Pape, 272 F.2d 365 (7th Cir. 1959).

$1481 \mathrm{~S}$. Ct. at 492.

15 See text at note 20 infra.

16 That language, appearing in $\S 1983$, is "rights ... secured by the Constitution" and action "under color of any statute, ordinance, regulation, custom, or usage of any state." See text at notes 20 and 22 infra. 
$C I O,^{17}$ the lower federal courts have been gradually and fitfully expanding the jurisdiction conferred by section $1343(3),{ }^{18}$ often to the dismay of those who would maintain a different balance of power between state and federal governments. ${ }^{19} \mathrm{It}$ would be well, therefore, to examine that jurisdiction and its relationship to section 1983, and to view in perspective the changes Monroe v. Pape has worked, and perhaps will work, on the power of the federal courts.

\title{
INTERRELATIONSHIP OF SECTIONS 1343 (3) AND 1983
}

The jurisdiction conferred upon the district courts by section 1343(3) is "arising under" jurisdiction. It "arises under" section 1983, which creates a cause of action to redress the deprivation of certain rights, privileges, and immunities. Section 1983 provides:
Every person who, under color of any statute, ordinance, regulation, custom, or usage of any state or Territory, subjects or causes to be subjected any citizen of the United States or other person within the jurisdiction thereof to the deprivation of any rights, privileges, or imnunities secured by the Constitution and laws, shall be liable to the party injured in an action at law, suit im eqnity, or other proper proceeding for rehef. 20

Section 1343(3) allows a suit to be brought in the district courts under section 1983 regardless of the amount in controversy. ${ }^{21}$ In language similar to that of section 1983, section 1343(3) provides:

\begin{abstract}
The district courts shall have original jurisdiction of any civil action authorized by law to be commenced by any person: .... (3) to redress the deprivation, under color of any state law, ordinance, regulation, custom or usage, of any right, privilege, or immunity secured by the Constitution of the United States or by any Act of Congress providing for equal rights of citizens or of all persons within the jurisdiction of the United States. ${ }^{22}$
\end{abstract}

This similarity in language calls for a close analysis of the interrelationship of sections 1983 and $1343(3)$. Normally, the failure to state a cause of action under section 1983 will also constitute a failure to state a claim within the jurisdiction of the district court under section 1343(3). But if the court dismisses for failure to state a cause of action, instead of for a lack of jurisdiction, it may be faced with difficult problems of pendent jurisdiction, ${ }^{23}$ particularly where the defendant's acts

17307 U.S. 496, 524 (1938). Sec text at notes 95-97 infra.

18 In McGuirc v. Todd, 198 F.2d 60 (5th Cir.), cert. denied, 344 U.S. 835 (1952), Judge Hutcheson, referring to this expansion of jurisdiction, said there is a "struggle to so extend the scope of these statutes [\$1343(3) and \$1983], that, upon the mere allegation in a suit for damages, of conspiracy, fraud, or malice, ... every action of a state officer, in the discharge of his duties of his office, may be re-examined in the federal court." Id. at 63.

${ }^{10}$ See, e.g., Tullier v. Giordano, 265 F.2d 1 (5th Cir. 1959) (dissenting opmion); Steier v. New York State Educ. Comm'r, 271 F.2d 13 (2d Cir. 1959); Sharp v. Lucky, 252 F.2d 910, (5th Cir. 1958) (dissenting opinion); McGuire v. Todd, 198 F.2d 60 (5th Cir.), cert. denied, 344 U.S. 835 (1952); Charlton v. City of Hialeah, 188 F.2d 421 (5th Cir. 1951); Egan v. City of Aurora, 174 F. Supp. 794 (N.D. Ill. 1959), aff'd, 275 F.2d 377 (7th Cir. 1960).

20 REv. StAT. \$ 1979 (1875), 42 U.S.C. § 1983 (1958).

21 The reasons for this exception to the general rule that the plaintiff must allege an ainount in controversy exceeding $\$ 10,000$, exclusive of interests and costs, 28 U.S.C. $\$ 1331$ (1958), are set forth in the opinion of Justice Stone in Hague v. CIO, 307 U.S. 496, 531 (1938). See also Comment, Federal Jurisdiction: Amount in Controversy in Suits for Nonmonetary Remedies, 46 CALIF. I. REv. 601 (1958).

2228 U.S.C. \&1343(3) (1958).

23 See, e.g., Hurn v. Oursler, 289 U.S. 238 (1933). See generally Note on Pendent Jatrisdiction, Hart \& Wechster, THe Federar Courts and tHe Federal System 802f. (1953). 
can also be characterized as a tort under state law. ${ }^{24}$ Thus, the district courts may find themselves adjudicating many claims that could not otherwise be asserted in the federal courts. On the other hand, the differences in the language of these two sections may provide a handy means for denying jurisdiction, should the courts wish the plaintiff to resort to the judicial processes of the state. ${ }^{25}$

An analysis of federal power under section 1343 (3) must begin with the words "authorized by law." These words refer to section 1983 and require that the plaintiff state a cause of action within the scope of that section as a prerequisite to establishing jurisdiction under section 1343(3). Section 1983 does not, however, confer jurisdiction upon the district courts; ${ }^{20}$ but because it must be referred to in order to determine whether the court has power to entertain the suit under section $1343(3)$, many courts have treated it as actually conferring jurisdiction, ${ }^{27}$ or at least as combining with section 1343 (3) to confer jurisdiction over the plaintiff's claim to relief. ${ }^{28}$ In this the courts have erred. The purpose of section 1983 is to create a cause of action, as its language plainly indicates. ${ }^{20} \mathrm{It}$ does not specify the forum in which this cause of action may, or must, be asserted. In the usual case, a party seeking to assert a right under a federal statute must meet the requirements of 28 U.S.C. section 1331, which predicates entry to the district courts upon the existence of a specified amount in controversy..$^{30}$ Because section 1343(3) eliminates the necessity of pleading such an amount in a suit brought under section 1983, it is a non sequitur to say that section 1983 therefore confers jurisdiction upon the district courts. It does not confer jurisdiction, either alone or in combination with section 1343 (3). It merely creates a cause of action as to which Congress has seen fit to eliminate one of the jurisdictional requirements applicable to claims arising under other federal statutes. ${ }^{31}$

Once it is apparent that section 1983 does not confer jurisdiction upon the district courts, the differences in language between it and section 1343(3) become significant. There are two fundamental differences:

(1) Section 1983 creates a cause of action whenever the deprivation occurs under color of either state or territorial law. The district courts, however, have jurisdiction under section 1343 (3) only where the defendant is alleged to have acted under color of state law.

(2) Under section 1983, the cause of action extends to the deprivation of any

24 See text at notes 110-11 infra.

25 See text at notes $39-46$ infra.

26 An authoritative discussion of the respective functions of $\S \S 1343(3)$ and 1983 may be found in Dyer v. Kazuhisa ABE, 138 F. Supp. 220 (D. Hawaii 1956), rev'd, 256 F.2d 728 (9th Cir. 1958). The distinction between the sections is clearly drawn in Thomas v. Chamberlain, 143 F. Supp. 671 (E.D. Tenn. 1955), afj'd, 236 F.2d 417 (6th Cir. 1956).

27 See, e.g., Tate v. Arnold, 223 F.2d 782 (8th Cir. 1955) ; Jennings v. Nester, 217 F.2d 153 (7th Cir. 1953), cert. denied, 349 U.S. 958 (1955); Geach v. Moynahan, 207 F.2d 714 (7th Cir. 1953); Mitchell v. Greenough, 100 F.2d 184 (9th Cir.), cert. denied, 306 U.S. 659 (1938); Arkansas v. Central Sur. \& Ins. Corp., 102 F. Supp. 444 (W.D. Ark. 1952); Arroyo v. Puerto Rico Transp. Authority', 66 F. Supp. 1022 (D.P.R. 1946), af'd, 164 F.2d 748 (1st Cir. 1947).

28 See, e.g., Valle v. Stengel, 176 F.2d 697 (3d Cir. 1949); Johnson v. Stevenson, 170 F.2d 108 (5th Cir. 1958), cert. denied, 336 U.S. 904 (1949); Kenney v. Hatfield, 132 F. Supp. 814 (N.D. Ga. 1954), af'd, 232 F.2d 288 (6th Cir. 1956).

29 At least one federal court has confused $\S 1343(3)$ with $\S 1983$, treatimg $\S 1343(3)$ as creating a cause of action. Hoxie School Dist. No. 46 v. Brewer, 135 F. Supp. 296 (E.D. Ark. 1955).

30 See note 21 supra.

31 Sce opinion of Justice Stone in Hague v. CIO, 307 U.S. 496, 531 (1939). 
right, privilege, or immunity secured by the "lares" of the United States, whereas section 1343 (3) confers jurisdiction only where these interests are secured by "any Act of Congress providing for equal rights of citizens or of all persons within the jurisdiction of the United States."

These inconsistencies in language appear for the first time in the Revised Statutes of $1875,{ }^{32}$ which purported to codify then existing law. ${ }^{33}$ Part of that law was the act of April 20,1871. ${ }^{34}$ This act, as far as pertinent, referred only to action under color of state law and to rights secured by the Constitution. ${ }^{35}$ It did not refer to actions under color of territorial law, nor did it allude to any federal laws securing rights, privileges, or immunities, nuuch less "Acts" providing for equal rights. Perhaps there is no explanation for the addition of these words, ${ }^{36}$ other than careless draftsmanship. The legislative history of sections 1343(3) and $1983^{37}$ sheds little light upon the reason for the addition of any words to the Revised Statutes or for the differences in their language. ${ }^{38}$

Problems caused by the failure to include actions under color of territorial law within the provisions of section 1343 (3) inay have become largely moot with the granting of statehood to Alaska and Hawaii. But at least one district court has held that actions under color of territorial law could not be remedied in a federal court because of the restricted scope of section $1343(3) .^{39}$

32 Rev. Stat. \$ 1979 (1875); Rev. Stat. \$ 629 (1875).

33 The Revised Statutes were considered mere evidence of existing law. United States v. Moore, 26 Fed. Cas. 1306 (No. 15804) (C.C.W.D. Ala. 1878).

3417 Stat. 13 (1871). See notes 4 and 5 supra.

35 " $\mathrm{Be}$ it enacted by the Senate and House of Representatives of the United States of America in Congress assembled, That any person who, under color of any law, statute, ordinance, regulation, custom, or usage of any State, shall subject, or cause to be subjected, any person within the jurisdiction of the Umited States to the deprivation of any rights, privileges, or immunities secured by the Constitution of the United States, shall, any such law, statute, ordinance, regulation, custom, or usage of the State to the contrary notwithstanding, be liable to the party injured in any action at law, suit in equity, or other proper proceeding for redress; such proceeding to be prosecuted in the several district or circuit courts of the United States, with and subject to the same rights of appeal, review upon error, and other remedies provided in like cases in such courts, under the provisions of the act of the ninth of April, eighteen hundred and sixty-six, entitled 'an act to protect all persons in the United States in their civil rights, and to furnish the means of their vindication'; and the other remedial laws of the United States which are in their nature applicable in such cases. ..."17 Stat. 13 (1871).

${ }^{30}$ It has been argued that the words "Acts of Congress providing for equal rights ....." refer to the provisions of the Civil Rights Act of 1866, which provide for equal rights and which were codified in other sections of the Revised Statutes. Comment, The Proper Scope of the Civil Riglits Acts, 66 HARv. L. Rev. 1285, 1292-93 (1953) ; Note, 43 ILL. L. Rev. 105, 110-11 (1948). This argument explains why these words could have been added to $\S 1343(3)$, but it does not explain why the words "and laws" were added to $\$ 1983$.

${ }^{37}$ This history, as applicable to the instant problem, is discussed in Comment, The Proper Scope of the Civil Rights Acts, 66 HARv. L. Rev. 1285, 1292-93 (1953) ; Note, 43 III. L. REv. 105 (1948).

38 There is no easy method of reconciling the discordant provisions of $\S 1983$ and $\S 1343(3)$. See generally Comment, The Proper Scope of the Civil Rights Acts, stpra; Note, 16 Geo. Wast. L. Rev. 260 (1948); Note, 43 Irr. L. Rev. 105 (1948); Note, 26 Texas L. Rev. 531 (1948); Note, 47 Coruar. L. Rev. 1082 (1947).

30 Mo Hock Ke Lok Po v. Stainback, 74 F. Supp. 852 (D. Hawaii 1947), rev'd on other grounds, 336 U.S. 368 (1948). Contra, Dyer v. Kazuhisa ABE, 138 F. Supp. 220 (D. Hawaii 1956), rev'd on other grounds, 256 F.2d 728 (9th Cir. 1958); International Longshoremen's \& Warehousemen's Union v. Ackerman, 82 F. Supp. 65 (D. Hawaii 1948), rev'd on other grounds, 187 F.2d 860 (9th Cir. 1951) ; Alesna v. Rice, 74 F. Supp. 865 (D. Hawaii 1947), aff'd, 172 F.2d 176 (9th Cir. 1949). 
The most significant difference in language is found in the words "secured by the ... laws" in section 1983 and "secured by ... any Act of Congress providing for equal rights of citizens or of all persons within the jurisdiction of the United States" in section 1343 (3). A hteral reading of section 1343(3) would compel the conclusion that the district courts have no power to redress the deprivation of rights secured by the laws of the United States, such as the Social Security Act, unless those laws expressly provide for the equality of classes or persons.

Yet in Bomar v. Keyes, ${ }^{40}$ apparently the first case to consider the question, Judge Learned Hand ignored this language and held that the district court had jurisdiction to redress the deprivation of any right, privilege, or immunity created by a federal statute. ${ }^{2}$ Plaintiff, a teacher in the Brooklyn public schools, was discharged from her job because she had absented herself several weeks during the school term to serve on a federal jury. The Second Circuit ordered her reinstatenent on the ground that a person cannot be penalized for the exercise of a privilege conferred by the laws of the United States. Speaking for a unanimous court, Judge Hand said:

The jurisdiction of the district court therefore depends upon whether the Judiciary Act, which thus indirectly qualified women as federal jurors, conferred upon them a "privilege" under the Civil Rights Act. Although the books are full of cases under that statute concerning the deprivation of rights and privileges, secured by the Constitution, we have been unable to find any in which the right or privilege at stake was secured by a "law" of the United States. Nevertbeless, this language is so plain that the only question is whether this particular law secured to the plaintiff a "privilege." By that word we understand a freedom to assert a legal right or a legal power; in this case, the power to take part in the administration of justice. ${ }^{43}$

Perhaps Judge Hand confused section 1983 with section 1343(3). ${ }^{44}$ He could not have found jurisdiction in the district court had he taken section 1343(3) at face value, since the Judiciary Act is not one which purports to confer "equal rights." The most that can be said for his approach is that he made an attempt to forge sections 1343 (3) and 1983 into a coherent whole by aligning the jurisdiction of the district courts with the elements of the cause of action "authorized by law" to be litigated therein. But the unalterable fact is that the language of sections 1343(3) and 1983 is plainly inconsistent. Unless the courts are willing to ignore this inconsistency, they must recoguize that their jurisdiction under section 1343 (3) is narrower than the cause of action created by section 1983.45 The dubi-

40162 F.2d 136 (2d Cir.), cert. denied, 332 U.S. 825, rehearing denied, 332 U.S. 845 (1947), cert. denied, 336 U.S. 909 (1948).

${ }^{41}$ Cf. Holt v. Indiana Mfg. Co., 176 U.S. 68 (1900).

42 Accord, Pugach v. Sullivan, 180 F. Supp. 66 (S.D.N.Y.), aff'd on other groutrds, sub nom. Pugach v. Dollinger, 277 F.2d 739 (2d Cir. 1960), af'd, 29 U.S.L. WEEK 4247 (U.S. Feb. $27,1961)$. In at least two other cases, the district courts assumed they had jurisdiction of suits to redress the deprivation of rights conferred by an act of Congress. See Hoffunan v. O'Brien, 88 F. Supp. 490 (S.D.N.Y.), aff'd, 339 U.S. 955 (1949) (per curiam); De Vasto v. Hoyt, 101 F. Supp. 908 (S.D.N.Y. 1951). Cf. Love v. Chandler, 124 F.2d 785 (8th Cir. 1952).

43 162 F.2d 136, 137 (1947). (Emphasis added.)

44 See text at notes 26-31 supra.

45 Walker v. Bank of America Nat'l Trust \& Sav. Ass'n, 268 F.2d 16 (9th Cir.), cert. dcnied, 361 U.S. 903, rehearing denied, 361 U.S. 940 (1959) (by implication); Insular Police Comm'n v. Lopez, 160 F.2d 673 (1st Cir.), cert. denied, 331 U.S. 855 (1947) (alternate holding); McGuire v. Amrein, 101 F. Supp. 414 (D.Md. 1951). Cf. Schatte v. International Alliance of Theatrical Stage Employees, 182 F.2d 158 (9th Cir.), cert. denied, 340 U.S. 827, rehearing denied, 340 U.S. 885 (1950).

Arguments for the proposition that the words "any Act of Congress providing for equal rights ..." should be biterally construed may be found in Counment, The Proper Scope of the Civil Rights Acts, 66 Harv. L. Rev. 1285 (1953); Note, 16 Geo. Wasr. L. Rev. 260 (1948); Note, 47 ColuM. L. REv. 1082 (1947). 
ous origin of these differences should not offer an opportunity for forthright judicial legislation. If the courts are to read the statutes, it would seem proper that they read them as they were written. ${ }^{48}$

II

PROPER PARTIES PLAINTIFF AND DEFENDANT UNDER SECTIONS 1343 (3) AND 1983

In Monroe v. Pape, the Supreme Court did not question the fact that the Monroes were proper parties to bring suit in the district court under section 1983. Indeed the Court could not, since it had been the rights of the Monroes that had been infringed. Yet in other circumstances the question of who may invoke the jurisdiction of the district courts in suits brought under section 1983 has caused considerable confusion.

Mention of the party plaintiff is found in the introductory clause of section 1343 , which provides that "the district courts shall have original jurisdiction of any civil action authorized by law to be commenced by any person ...." ${ }^{27}$ The person "authorized by law" is defined in section 1983 as the "party injured."48 No federal court has ever expressed a doubt that the words "any person" and "party injured" refer at least to a natural person suing on his own behalf, ${ }^{49}$ for the very purpose of the Civil Rights Acts was to protect the rights of such persons, in particular the Negro. 50

But do these words refer only to the one actually irjured, or may a representative, such as his survivor, the admimistrator of his estate, or even his umion bring suit on his behalf in the district courts under section 1983? Where the decedent's survivor or administrator sues for damages, the cause of action has been deemed to survive..$^{51}$ And rightly so, it seems, for otherwise the courts would be in the anomalous position of being able to redress minor deprivations of a person's rights,

46 Even if the courts read $\S 1343(3)$ as it is written, they can still avoid the consequences of the differences in language between it and $\S 1983$ where the plaintiff alleges an aunount in controversy exceeding $\$ 10,000$, exclusive of interest and costs. Since plaintiff's claim will arise under a federal statute ( $\$ 1983$ ), the court will be able to assume jurisdiction under 28 U.S.C. $\$ 1331$ (1958). See text at note 30 supra.

${ }^{4 \tau}$ An oblique reference to the party plaintiff may be found in subsection (3) of $\S 1343$, which speaks of "any right, privilege, or immunity secured by the Constitution of the United States or by any Act of Congress providing for equal rights of citizens or of all persons within the jurisdiction of the United States." (Emphasis added.) See text at note 22 supra.

48 A governmental umit, such as a state school district, is not a "person" entitled to bring suit against the state in a federal court under $\S 1983$, even though it may be the "party injured." Dallas Independent School Dist. v. Edgar, 255 F.2d 455 (5th Cir. 1958).

49 Capacity to sue in the district courts under $\$ 1983$ is not determined by rule 17 (b) of the Federal Rules of Civil Procedure, which looks to state law, but by federal law as manifested in the words "every person." McCollun v. Mayfield, 130 F. Supp. 112 (N.D. Cal. 1955). Thus, even though a state prohibits civil actions by prisoners, they may sue for damages under $\$ 1983$ in the federal courts, ibid., and perhaps in the state courts, under the supremacy clause of the Constitution.

50 The right to bring suit under the Civil Rights Acts is not based upon the plaintiff's race or color, however. Egan v. City of Aurora, 174 F. Supp. 794 (N.D. Ill. 1959), aff'd, 275 F.2d 377 (7th Cir. 1960). "Though the original purpose of civil rights legislation was to secure the civil and political rights of Negroes, it is clear today that such legislation embraces the protection of basic civil and political rights of all persons within the jurisdiction of the respective States, whether citizen or not, from the abuse of State power." Id. at 797. Accord, Truax v. Raich, 239 U.S. 33 (1915) (aliens). Cf. Princepe v. Ault, 62 F. Supp. 279 (N.D. Ohio 1945) (aliens).

51 Nelson v. Knox, 230 F.2d 483 (6th Cir. 1956) (personal representatives) ; Davis v. Johnson, 138 F. Supp. 572 (N.D. Ill. 1955) (administratrix). 
but not those which cause his death. ${ }^{62}$ Where unions have sued in a representative capacity, they have been held able to bring suit under section $1983,{ }^{53}$ though technically they are not the "party injured." This approach would seem to have some justification in light of the purpose of the Civil Rights Acts, since it can be argued that utilization of a union's "war chest" to protect the rights of its members advances, rather than defeats, the goals of fair and equal treatment under the law.

Even where a union or corporation has purported to sue on its own behalf as the "party injured" rather than in a representative capacity, the courts have generally found jurisdiction under section $1343(3) .{ }^{54}$ The argument to the contrary has been that unions and corporations do not lave civil rights, and thus cannot bring suit to redress a deprivation of rights peculiar to individuals. ${ }^{65}$ This argument is not without precedent. In Hague v. $\mathrm{CIO},{ }^{56}$ the Supreme Court held that a union, and a fortiori a corporation, ${ }^{57}$ could not redress a denial of the freedoms of speech and assembly under section $1983 .{ }^{58}$ Nevertheless, this aspect of the Hague case has been largely ignored by the lower courts ${ }^{50}$ and perhaps the law of

52 In Davis v. Johnson, supra, the court concluded that "in order to carry out the purpose of the statute [\$1983] and to prevent an injustice which would arise if plaintiff were to go remediless, it should construe the words 'party injured' to include the administratrix of the estate of one who was killed in violation of Section 1983." Id. at 575.

53 See, e.g., United Elec. Radio \& Mach. Workers of America, CIO v. Baldwin, 67 F. Supp. 235 (D. Conn. 1946). Cf. International Longshoremen's \& Warehousenien's Union v. Ackernıan, 82 F. Supp. 165 (D. Hawaii 1948), rev'd on other grounds, 187 F.2d 860 (9th Cir.), cert. denied, 342 U.S. 859 (1951).

54 See, e.g., McCoy v. Providence Journal Co., 190 F.2d 760 (1st Cir.), cert. denied, 342 U.S. 894 (1951) (right to inspect public records) ; Watchtower Bible \& Tract Soc'y v. Los Angeles County, 181 F.2d 739 (9th Cir. 1950) (freedom of religion); Magtab Publishing Corp. v. Howard, 169 F. Supp. 65 (W.D. Va. 1959) (freedom of speech) ; NAACP v. Patty, 159 F. Supp. 503 (E.D. Va. 1958), modified sub nom. NAACP v. Harrison, 360 U.S. 167 (1959) (freedom of speech); Tribune Review Publishing Co. v. Thomas, 153 F. Supp. 486 (W.D.Pa. 1957), aff'd, 254 F.2d 883 (3d Cir. 1958) (freedom of press); Webb. v. State Univ. of N.Y., 125 F. Supp. 910 (N.D.N.Y.), appeal dismissed, 348 U.S. 867 (1954) (rigbt to affiliate with national fraternity); AFL v. Watson, 60 F. Supp. 1010 (S.D. Fla. 1945) (freedoins of speech, press, assenibly). Cf. Grosjean v. American Press Co., 297 U.S. 233 (1936).

See generally Latrti, Corporations 89-90 (1959); Poole, Statutory Remedies for the Protection of Civil Rights, 32 ORE. L. REv. 210 (1953); Counment, Civil Actions for Violations of Civil Rights; Note, 7 Baylor L. Rev. 224 (1955); Note, 66 Yade L.J. 545 (1957); Note, 28 CAIIF. L. REv. 388 (1939); Note, 38 Mich L. REv. 57 (1938).

55 See, e.g., Hallmark Prods. v. Mosley, 190 F.2d 904 (8th Cir. 1951) (corporation); International Ladies' Garment Workers Union, AFL v. Seamprufe, 121 F. Supp. 165 (E.D. Okla. 1954) (umion) ; Local 309, United Furniture Workers of America, CIO v. Gates, 75 F. Supp. 620 (N.D. Ind. 1948) (union) ; Mickey v. Kansas City, 43 F. Supp. 739 (W.D. Mo. 1942) (corporation).

56307 U.S. 496 (1938).

57 Justice Stone stated that a corporation "cannot be said to be deprived of the civil rights of freedom of speech and assembly, for the liberty guaranteed by the due process clause is the liberty of natural, not artificial persons." Id. at 527.

58 Suit was brought by a union and its members, as individuals, to enjoin the mayor, chief of police, and other officials of Jersey City from interfering with the distribution of printed matter and the holding of nreetings to "explain to workingmen the purposes of the National Labor Relations Act, the benefits to be derived from it, and the aid which the Conmittee for Industrial Organization would furnish workingmen to tliat end." Id. at 503. A majority of the Justices agreed that the union had no rights which it could enforce under $\$ 1983$. Id. at 500 (opinion of Justice Roberts); id. at 518 (opinion of Justice Stone); id. at 532 (opinion of Chief Justice Hughes).

59 See cases cited note 54 sutpra. 
the future can be found in a recent decision of a federal district court, NAACP v. Patty, ${ }^{60}$ wherein it was said:

There is no reasonable ground at this time to deny the protection afforded by the Civil Rights Acts to corporations engaged through their agents in public speech and in circulation of bterature designed to protect the rights of natural persons in whose interests these enactments were originally passed. Since "person" in the Fourteenth Amendment has been broadly construed to include corporations in the protection of property rights, there is no good reason why the same liberality of interpretation should not be used when a corporation is formed for protecting civil liberties. ${ }^{61}$

Despite this compelling argument, it is hard to see why corporations, or unions either, for that matter, should be able to redress deprivations of due process and equal protection in the federal courts under section 1983. They are not "persons" in the normal sense of the word; they are artificial entities existing apart from their shareholders and members. They do not vote in national elections, nor do they worship. They cannot be arrested; they cannot be made unequal because of race or color, since they have no race or color. Why, therefore, should they come within the protection of the Civil Rights Acts? These acts were primarily aimed at securing the rights of a specific class of individuals, namely, the Negro and his Northern sympathizers, who could find hittle solace in the South at the close of the Civil War. ${ }^{62}$ It seems unlikely that Congress would have deemed it necessary or advisable to afford similar protection to corporations or unions as separate entities, since any deprivation of their rights could be redressed by their members or shareholders insofar as it affected them. But it could be argued that corporations should be allowed to sue in a representative capacity, just as are unions, ${ }^{63}$ and perhaps this is the underlying rationale of the court's language in Patty.

Once it has been established that the plaintiff is a "person" who may invoke the jurisdiction of the district court under section 1343(3), the next step is to determine whether the defendant may be sued. This, too, is a jurisdictional question, since the court has jurisdiction only of those suits that are "authorized by law." Section 1343(3) is of no assistance, for it speaks in terms of the plaintiff, not adverting to the defendant except to say that whoever he (or it) is, he nust act under color of state law. Under section 1983 suit is authorized against "every person who, under color of any statute... of any state or Territory subjects or causes to be subjected any citizen of the United States or other person within the jurisdiction thereof to the deprivation of any rights, privileges, or immunities ...." Thus, unless the defendant is a "person" within the neaning of section 1983, the suit must be dismissed for lack of jurisdiction.

The words "every person" clearly refer to natural persons. They do not include the members of a court as a body, ${ }^{64}$ nor do they refer to a city, as all the members of the Court in Monroe agreed..$^{65}$ In a dictun, Justice Douglas, speaking for the

60159 F. Supp. 503 (E.D. Va. 1958), modified sub. nom. NAACP v. Harrison, 360 U.S. 167 (1959).

61 Id. at 519.

62 See generally RandaII, The Civin. War and Reconstruction (1937).

03 Cases cited note 53 supra.

64 Handy Cafe v. Justices of the Superior Court, 248 F.2d 485 (1st Cir.), cert. denied, 356 U.S. 902 (1957).

65 Prior to the Monroe case, it had been generally held that a city is not a "person" witlin the meaning of $\S 1983$, at least where the plaintiff was suing for damages, See, e.g., Cuiksa v. City of Mansfield, 250 F.2d 700 (6th Cir.), cert. denied, 356 U.S. 937 (1957); Agnew v. City of Compton, 239 F.2d 226 (9th Cir.), cert. denied, 353 U.S. 959 (1956); Cobb v. City of Malden, 202 F.2d 701 (1st Cir. 1953) ; Hewitt v. City of Jacksonville, 188 F.2d 423 (5th Cir.), cert. denied, 342 U.S. 835 (1951); Shuey v. Michigan, 106 F. Supp. 32 (E.D. Mich. 1952). But 
majority, said that sometimes a distinction had been made between suits for damages and suits for equitable relief, the courts treating a city as a "person" in the latter, but not in the former ${ }^{68}$ Henceforth, he said, a city may never be made a defendant in a suit brought under section 1983, regardless of the rehief sought. ${ }^{67}$

Justice Douglas relied exclusively upon legislative history and did not reach policy or constitutional considerations in determining that a city is not a "person" within the meaning of section $1983 .{ }^{68} \mathrm{~A}$ similar conclusion could have been reached lad he strictly construed the language of section 1983 that describes the defendant as the person who "subjects ... or causes a person to be subjected ... to the deprivation of any rights, privileges, or immunities ...." The City of Chicago did not itself subject the Monroes to harm, nor could it have been held that the mere hiring of the individual defendants caused the Monroes to be subjected to a deprivation of their rights, unless the Court would have been willing to stretch the concept of causation to its farthest reaches. ${ }^{60}$

Whether conspirators are "persons" who may be sued in the district courts under section 1983 is a difficult question and one not answered by the decision in Monroe v. Pape. ${ }^{70}$ A literal interpretation of sections 1983 and 1343(3) would indicate they are not, for neither expressly mentions a conspiracy or conspirators. A najority of the lower courts, however, have either held or implied that a conspirator is a "person" within the meaning of section 1983.71

often the courts avoided the issue altogether by holding the city immune from liability. Sce, e.g., Charlton v. City of Hialeah, 188 F.2d 241 (5th Cir. 1951) ; McConnell v. City of Detroit, 98 F. Supp. 901 (E.D. Mich. 1951).

60 Compare cases cited supra note 65, with, e.g., Walton v. City of Atlanta, 131 F.2d 693 (5th Cir.), cert. denied, 340 U.S. 823 (1950) ; Hannan v. City of Haverhill, 120 F.2d 87 (1st Cir.), cert. denied, 314 U.S. 641 (1941); Whisler v. City of West Plains, 43 F. Supp. 654 (W.D. Mo. 1942), affd, 137 F.2d 938 (8th Cir. 1943); Zimmerman v. Village of London, 38 F. Supp. 582 (S.D. Ohio 1941).

6781 S. Ct. at 486 n.50.

68 Id. at 484-86.

60 But if the police officers had committed similar acts in the past and yet had been retained on the police force, it could have been argued that their immediate superiors caused the Monroes to be imjured. Indeed, the lower courts lave frequently allowed suit to be brought under $\$ 1983$ against the supervisor or the employer of the one actually causing the harm. See, e.g., Lewis v. Brautigan, 277 F.2d 124 (5th Cir. 1955) (acts of deputy imputed to sheriff); Fleming v. South Carolina Elec. \& Gas Co., 224 F.2d 752 (4th Cir. 1955) (per curiam) (bus company held liable for acts of driver), see discussion of this case at note 160 infra; Lynch v. City of Muskogee, 47 F. Supp. 589 (E.D. Okla. 1942) (employer-employec); Whisler v. City of West Plains, 43 F. Supp. 654 (W.D. Mo. 1942), aff'd, 137 F.2d 938 (8th Cir. 1943) (employer-employee). Contra, Cobb v. City of Malden, 202 F.2d 701 (1st Cir. 1953).

70 Neither the majority nor the concurring opinions allude to a conspiracy. Apparently it was not alleged that the police conspired to deprive plaintiffs of their civil rights. In a dietum, lowever, Justice Frankfurter seems to indicate that $\S 1983$ might also have been aimed at conspiracies. $81 \mathrm{~S}$. Ct. at 522.

71 Hoffman v. Halden, 268 F.2d 280 (9th Cir. 1959); Walker v. Bank of America Nat'l Trust \& Sav. Ass'n, 268 F.2d 16 (9th Cir.), cert. denied, 361 U.S. 903, rehearing denied, 361 U.S. 941 (1959) (by implication); Roark v. West, 251 F.2d 956 (5th Cir.), cert. denied, 357 U.S. 940, rehearing denied, 358 U.S. 844 (1958) (by implication); Baldwin v. Morgan, 251 F.2d 780 (5th Cir. 1958) (by implication); McShane v. Moldovan, 172 F.2d 1016 (6th Cir. 1940); Pickmg v. Pennsylvania R.R., 151 F.2d 240, rehearing denied, 152 F.2d 753 (3d Cir. 1945); Copely v. Sweet, 133 F. Supp. 502 (W.D. Mich. 1955), cert. denied, 352 U.S. 887 (1956); Horn v. Peck, 130 F. Supp. 536 (W.D. Mich. 1955); Robeson v. Fanelli, 94 F. Supp. 62 (S.D.N.Y. 1950). Contra, Stafford v. Superior Court, 272 F.2d 407 (9th Cir. 1959); Jennings v. Nester, 217 F.2d 153 (7th Cir.), cert. denied, 349 U.S. 958 (1954); Eaton v. Coullard, 217 F.2d 446 (7th Cir. 1954), cert. denied, 350 U.S. 915 (1955); Mitchell v. Greenough, 100 F.2d 184 (9th Cir. 1938). Cf. Brasier v. City of Tulsa, 268 F.2d 558 (10th Cir.), cert. denied, 361 U.S. 964 (1959) (city cannot conspire with itself). 
Defining "persons" to include conspirators is complicated by the fact that jurisdiction over conspiracies to deprive the plaintiff of his right to equal protection or his right to vote is expressly conferred by another section of the Civil Rights Acts, 28 U.S.C. section 1343(1).$^{72}$ This section does not purport to be exclusive, however, and it is at least arguable that conspirators should also be subject to federal jurisdiction under section 1343(3) whenever they seek to accomplish the same ends prohibited an individual by section $1983 .{ }^{73}$ Indeed, the words "causes to be subjected" found in section 1983 could be considered an oblique reference to a conspirator who plans the injury, but does not actively partake in its infliction..$^{74}$

But even if a conspirator is a "person" within the ineaning of section 1983, a distinction must be drawn between different kinds of conspirators. It is one thing to say that state officials who conspire to deprive the plaintiff of his federal rights should be subject to redress in the district courts, ${ }^{75}$ but quite another to say that a civil conspiracy may be used to bring the acts of a private citizen under color of state law ${ }^{76}$ where otherwise he would not be subject to the provisions of sections 1983 and $1343(3){ }^{77}$ To consider a private citizen a "person" within the jurisdiction of the court would markedly expand that jurisdiction, whereas to hold "persons" to include conspirators who are already state officials would simply elimi-

72 Section 1343(1) provides: "The district courts shall have original jurisdiction of any civil action authorized by law to be commenced by any person: To recover damages for injury to his person or property, or because of the deprivation of any right or privilege of a citizen of the United States, by any act done in furtherance of any conspiracy mentioned in section 1983 of title $42 ; \ldots$. . 28 U.S.C. $\$ 1343$ (1) (1958).

Section 1985 mentions the following conspiracies: "(3) If two or more persons in any State or Territory conspire or go in disguise on the highway or on the premises of another, for the purpose of depriving, either directly or indirectly, any person or class of persons of the equal protection of the laws, or of equal privileges and immunities under the laws; or for the purpose of preventing or hindering the constituted authorities of any State or Territory from giving or securing to all persons within such State or Terrtiory the equal protection of the laws; or if two or more persons conspire to prevent by force, intimidation, or threat, any citizen who is lawfully entitled to vote, fron giving his support or advocacy in a legal manner, toward or in favor of the election of any lawfully qualified person as an elector for President or Vice President, or as a Menuber of Congress of the United States; or to injure any citizen in person or property on account of such support or advocacy; in any case of conspiracy set forth in this section, if one or more persons engaged therein do, or eause to be done, any act in furtherance of the object of such conspiracy, whereby another is injured in his person or property, or deprived of having and exercising any right or privilege of a citizen of the United States, the party so injured or deprived nuay have an action for the recovery of damages, occasioned by such injury or deprivation, against any one or more of the conspirators." REv. STAT. § 1980 (1875), 42 U.S.C. \& 1985 (1958).

73 The argunent to the contrary is found in Jennings v. Nester, 217 F.2d 153 (7th Cir.), cert. denied, 349 U.S. 958 (1955), where it was stated that "Section 1983 does not mention conspiracy, while Section 1985 does. Therefore, the Act creates a cause of action for a conspiracy to deny equal protection but not for a conspiracy to deny due process." Id. at 154 . See also Note, 58 Micr. L. REv. 786 (1960).

74 In Hoffnian v. Halden, 268 F.2d 280 (9th Cir. 1959), perhaps the court had these words in mind when it said "what one person can do, two or more can do in concert-this is all a civil conspiracy is, concerted action or a sort of civil partnership in the conumission of an injury wherein one may act for his partner, and both may be bound." (Enıphasis added.) Id. at 292.

75 See, e.g., McShane v. Moldovan, 172 F.2d 1016 (6th Cir. 1949); Horn v. Peck, 130 F. Supp. 536 (W.D. Mich. 1955).

${ }^{70}$ See, e.g., Baldwin v. Morgan, 251 F.2d 780 (5th Cir. 1958). Cf. Arkansas v. Central Sur. \& Ins. Corp., 102 F. Supp. 448 (W.D. Ark. 1952) ; Llano Del Rio Co. of Nev. v. Anderson-Post Hardwood Lumber Co., 79 F. Supp. 382 (W.D. La. 1948).

77 See text at note 156 infra. 
nate the necessity of perhaps bringing two suits to redress the same wrong. ${ }^{78}$ This problem will be further discussed in connection with the phrase "action under color of state law." "78

Once the defendant is found to be a "person" within the meaning of section 1983, however, he still may not be subject to suit. The broad language of that section, stating that "every person . . . shall be liable," has forced a majority of the federal courts to create a doctrine of immunity in order to shield certain public officials, such as judges and prosecutors, from civil hability arising from the performance of their official duties ${ }^{80} \mathrm{~A}$ suit against one of these persons is not, there-

78 Overt acts are required before the conspirators can be subject to redress under $\S 1983$. The conspiracy in itself is not an actionable wrong. Hoffman v. Halden, 268 F.2d 280 (9th Cir. 1959).

70 See text at notes $165-79$ infra.

80 In Tenney v. Brandhove, 341 U.S. 367, rehearing denied, 342 U.S. 843 (1951), state legislators were held immune froin suit under $\$ 1983$. State judges have also been held immune, either absolutely, Francis v. Crafts, 203 F.2d 809 (1st Cir.), cert. denied, 346 U.S. 835 (1953); Curry v. Ragan, 257 U.S. 449 (5th Cir.), cert. denied, 358 U.S. 851 (1958); Stift v. Lynch, 267 F.2d 237 (7th Cir. 1959); Tate v. Arnold, 223 F.2d 782 (8th Cir. 1955); Larsen v. Gibson, 267 F.2d 386 (9th Cir.), cert. denied, 361 U.S. 848 (1959), or when they have jurisdiction over parties and subject matter, Kenny v. Fox, 232 F.2d 288 (6th Cir.), cert. denied, 352 U.S. 855 (1956) ; Cuiksa v. City of Mansfield, 250 F.2d 700 (6th Cir. 1957); Holmes v. Henderson, 249 F.2d 529 (9th Cir. 1957) ; Ryan v. Scoggin, 245 F.2d 54 (10th Cir. 1957) ; Spriggs v. Pioneer Carissa Gold Mines, 251 F.2d 61 (10th Cir. 1957). Only the Third Circuit has held that judges are not immune, Picking v. Pennsylvania R.R., 151 F.2d 240, rehearing denied, 152 F.2d 753 (3d Cir. 1945), and has steadfastly refused to change its position, despite the determined efforts of at least one litigant, Ginsburg v. Stern, 225 F.2d 245 (3d Cir. 1955), cert. denied, 356 U.S. 932, rehearing denied, 356 U.S. 954 (1957), 251 F.2d 50 (3d Cir. 1958), 263 F.2d 457 (3d Cir.), cert. denied, 361 U.S. 817, rehearing denied, 361 U.S. 898 (1959), 263 F.2d 458 (3d Cir. 1959).

Apart fron judges, the lower federal courts have often conferred absolute immunity upon those state officials whose actions could be characterized as quasi-judicial. Stift v. Lynch, 267 F.2d 237 (7th Cir. 1959) (prosecuting attorney); Jennings v. Nester, 217 F.2d 153 (7th Cir.), cert. denied, 349 U.S. 958 (1954) (state's attorney); Dunn v. Estes, 117 F. Supp. 146 (D. Mass. 1953), aff'd, 216 F.2d 709 (1st Cir. 1954) (probation officer); Morgan v. Sylvester, 125 F. Supp. 380 (S.D.N.Y.1954), aff'd, 220 F.2d 758 (2d Cir.), cert. denied, 350 U.S. 867 (1955), rehearing denied, 350 U.S. 919 (1958) (governor); Miller v. Director, Middletown State Hosp., 146 F. Supp. 674 (S.D.N.Y. 1956), aff'd, 243 F.2d 527 (2d Cir. 1957) (director of state mental institution); Smith v. Mosier, 148 F. Supp. 638 (W.D.Mich. 1957) (prosecuting attorney, sheriff willfully introducing false evidence in criminal trial) ; Bartlett v. Duty, 174 F. Supp. 94 (N.D. Ohio 1959) (witness called by court in sanity hearing, resident physicians and superintendent of state mental hospital).

Sometimes only a qualified immunity has been extended to state officials. Curry v. Ragan, 257 F.2d 449 (5th Cir.), cert. denied, 358 U.S. 851, rehearing denied, 358 U.S. 914 (1958) (pohice officers and county clerks carrying out orders of state court); Nelson v. Knox, 256 F.2d 312 (6th Cir. 1958) (mayor, members of city council, city commissioners); Francis v. Lyman, 216 F.2d 583 (1st Cir. 1954) (commissioners of correction, nnembers of parole board, superintendent of state prison farm and reformatory); Copely v. Sweet, 133 F. Supp. 502 (W.D. Mich. 1955), cert. denied, 352 U.S. 887 (1956) (detective, prosecuting attorney, court appointed counsel); Thompson v. Baker, 133 F. Supp. 247 (W.D. Ark. 1955) (constable); Ginsburg v. Stern, 125 F. Supp. 596 (W.D.Pa. 1954), aff'd, 225 F.2d 245 (3d Cir. 1955) (prothonotary).

Some officials, lrowever, have been held not immune from suit under $\$ 1983$. Carpenter v. Dethmers, 252 F.2d 131 (6th Cir. 1958) (warden, parole officer); Skinner v. Nehrt, 242 F.2d 573 (7th Cir. 1957) (clerk of county court); United States v. Carson, 126 F. Supp. 37 (W.D. Pa. 1954) (clerk of court); Morgan v. Null, 117 F. Supp. 11 (S.D.N.Y. 1953), cert. denied, 351 U.S. 914 (1955) (assistant district attorney, medical examiner for district attorney).

Immunity from suit under $\S 1983$ is to be determined as a matter of federal law, Nelson v. Knox, 256 F.2d 312 (6th Cir. 1958) ; Morgan v. Null, 117 F. Supp. 11 (S.D.N.Y. 1953), cert. denied, 351 U.S. 914 (1955). Contra, Charlton v. City of Hialeah, 188 F.2d 421 (5th Cir. 1951). In 1 Moore, Federat Practice 33732 (2d ed. 1959), the author quotes Sola Elec. Co. v. Jeffer- 
fore, authorized by law, and must be dismissed for lack of jurisdiction. ${ }^{81}$

In Monroe v. Pape, the Supreme Court did not advert to a possible defense that the pohice officers might have been immune from liability under section 1983 . In any event, it is highly unlikely that such a defense would have been sustained. ${ }^{82}$ To have granted immumity to the policemen would have emasculated section 1983, for then all officials in the lower echelons of state and local governments would be equally entitled to assert that they too should be immune.

Indeed, to grant immunity to any state official contravenes the spirit as well as the language of section 1983. The interpretation of the words "every person" to mean "not every person" cannot be justified if section 1983 is to be taken at face value as an expression of congressional intent. ${ }^{83}$ The determmation of who should be subject to suit under that section is a policy issue of the gravest consequence. It is one that should be decided by Congress, rather than by the courts, particularly where Congress lias spoken in terms too clear to be misunderstood.

\section{III}

\section{STATING A CLATM WITHIN THE JURISDICTION OF THE COURT UNDER} SECTION $1343(3)$

To state a claim within the jurisdiction of the district court under section 1343 (3), the plaintiff must allege: (1) the deprivation of a right, privilege, or immunity secured by the Constitution or by an Act of Congress providing for equal rights; and (2) action under color of a state law, statute, ordinance, regulation, custom, or usage. The scope of that jurisdiction depends, in turn, upon the interpretation given to "rights, privileges, or immunities" and upon the court's willingness to find some form of state action in the alleged infringement of plaintiff's rights.

\section{A. Rights, Privileges, and Immunities}

Two types of rights, privileges, and immunities are within the jurisdiction of the district courts under section $1343(3):(1)$ those secured by the Constitution; and (2) those secured by an Act of Congress providing for equal rights. The latter

son Co., 317 U.S. 173, 176 (1942), for the proposition that "state laws purporting to cloak state officials with immunity from habihty incurred in the performance of their official functions do not apply in suits brought under the federal Civil Rights Act for when a federal statute condemns an act as unlawful the extent and nature of the legal consequences ... are ... federal questions the answers to which are to be derived from the statute and the federal pohicy which it has adopted. To the federal statute and pohicy, conflicting state law and policy nust yield."

On the general subject of immunity from suit under $\$ 1983$, see Comment, The Doctrine of Official Innunitity under the Civil Rights Acts, 68 HARv. L. REv. 1228 (1955); Comment, Liability of Public Officers to Suit under Civil Rights Acts, 46 CoLUM. L. REv. 614 (1946); Note, Constitutional Law: Immunity of Judges under the Civil Rights Act, 3 OrLA. L. Rev. 80 (1950).

81 See text at notes 23-31 supra. The plaintiff may still be able to seek redress in the state tribunals, assuming similar immumity does not exist there also. See generally Keefe, Personal Tort Liability of Administrative Officers, 12 FORDHAar L. REv. 130 (1943); David, The Tort Liability of Public Officers, 12 So. CAL. L. REv. 127, 260, 368 (1939); Jennings, Tort Liability of Administrative Officers, 21 MINN. L. REv. 263 (1937).

82 Cf. Curry v. Ragan, 257 F.2d 449 (5th Cir.), cert. denied, 358 U.S. 851, rehearing denied, 358 U.S. 914 (1958).

83 The legislative history of the Third Civil Rights Act would seem to indicate that Congress intended to abolish all inmunities then existent under state or federal law, insofar as they could be used as a defense to suits hrought under the Act. See generally Comment, The Doctrine of Official Immunity under the Civil Rights Acts, 68 HARv. L. REv. 1288 (1955); Comment, Liability of Public Officials to Suit under the Civil Rights Acts, 46 Colvm. L. Rev. 614 (1946). 
rights have already been discussed. ${ }^{84}$ While there is some confusion as to what is meant by the words "providing for . . . equal rights," the plaintiff may be able to make an argument, using Bomar v. Keyes ${ }^{85}$ as precedent, that the courts should have jurisdiction to redress the deprivation of any right conferred by a federal statute. $^{88}$

Until the Supreme Court's decision in Monroe v. Pape, the meaning of the phrase "any right, privilege, or immunity secured by the Constitution" had been the cause of much dispute. ${ }^{87}$ Originally the Court distinguished between rights directly and indirectly conferred, holding that the latter were not "secured" by the Constitution. Thus, in Carter v. Greenhore, ${ }^{88}$ it held that the circuit court did not have jurisdiction of a suit to redress the impairment of plaintiff's contract with the state, on the ground that freedom from impairment of obligations was not a right "directly" secured by the Constitution. After stating that "it might be difficult to enumerate the several descriptions of rights secured to the individual by the Constitution, the deprivation of which, by any person, would subject the latter to an action for redress under [\$1983]," the Court added, with a sigh of relief, that "fortunately, it is not necessary to do so in this case." 80 Sixteen years later, in Holt v. Indiana Mfg. Co., ${ }^{30}$ it held that "rights, privileges, or immunities" referred only to civil rights, and not to property rights.

And so the matter stood for almost forty years. Then, in 1938, in a landmark decision, Hague v. $\mathrm{ClO}^{91}$ the Court sphit in attempting to define these rights. ${ }^{22}$ Although a majority of the Justices agreed that the individual plaintiffs had stated a claim within the jurisdiction of the district court when they alleged a deprivation of their rights to freedom of speech and assembly, ${ }^{93}$ they could not agree as to the grounds on which their decision should be placed. Mr. Justice Roberts, joined by Mr. Justice Black, ${ }^{94}$ asserted that these rights were "privileges and immunities" of national citizenship. Mr. Justice Stone, in a separate opinion, ${ }^{95}$ contended that they were rights protected by the due process clause, and hence

there is no occasion, for jurisdictional purposes or any other, to consider whether freedom of speech and of assembly are immunities secured by the privileges and immunities clause of the Fourteenth Amendment to citizens of the United States, or to revive the contention, rejected by this Court in the Slaughter House Cases, ..., that the privileges and immunities of United States citizenship, protected by that clause, extend beyond those which arise or grow out of the relationship of United States citizens to the national government.98

84 See text at notes $40-45$ supra.

85162 F.2d 136 (2d Cir.), cert. denied, 332 U.S. 825, rehearing denied, 332 U.S. 845 (1947).

80 See, e.g., cases cited note 42 supra.

87 See generally Poole, Statutory Remedies for the Protection of Civil Rights, 32 ORE. L. Rev. 210 (1953); Comment, The Proper Scope of the Civil Rights Acts, 66 HARv. L. REv. 1285 (1953); Comment, The Civil Rights Acts: Emergence of an Adequate Federal Civil Remedy?, 26 IND. L.J. 361 (1951) ; Note, 52 HARv. L. REv. 1136 (1939).

88114 U.S. 317 (1884).

89 Id. at 323.

80176 U.S. 68 (1900).

91307 U.S. 496 (1938).

92 A good discussion of the concept of "rights, privileges, and inumunities," as of 1938 and the Hague case, may be found in Note, 39 CoLUM. L. REv. 1237 (1939); Note, 52 HArv. L. REv. 1136 (1939).

93 See note 58 supra.

94307 U.S. at 500.

95 Id. at 524 .

90 Id. at 519. 
Justice Stone would have limited the scope of federal jurisdiction under section 1343 (3) to suits to redress only those denials of due process where the underlying interest was inherently incapable of a money valuation. ${ }^{97}$ Though his views did not reflect those of a majority of the Justices, his analysis of the phrase "rights ... secured by the Constitution" as referring to the rights of due process and, a fortiori, equal protection found immediate acceptance in the lower federal courts. $^{.8}$ These courts, however, ignored Justice Stone's attempt to restrict their jurisdiction to suits to redress an "unconstitutional infringement of a right of personal liberty not susceptible of a valuation in money"s9 and began to entertain claims of infringement of a wide variety of property and personal interests. 100 Indeed, the expansion of federal jurisdiction under section 1343(3) in the years following Hague v. CIO can best be told in terms of the increasing willingness of the district courts to redress any deprivation of due process or equal protection, ${ }^{101}$ regardless of the nature of the underlying interest. ${ }^{102}$

In Monroe v. Pape, the Supreme Court has given its approval to this expansion of jurisdiction by unanimously agreeing that the purpose of the Third Civil Rights Act was to provide a remedy for the deprivation of rights secured by the fourteenth amendment, including the right to due process. Analyzimg legislative history and drawing heavily upon the title of the act itself - "An Act to enforce the Provisions of the Fourteenth Amendment and for other Purposes"-Justice Douglas concluded that "an allegation of facts constituting a deprivation ... of a right gnaranteed by the Fourteenth Amendment satisfies to that extent the requirement of [\$1983]."103 Justice Frankfurter agreed, stating that "if petitioners have alleged

$87 \mathrm{Id}$. at 530.

88 See, e.g., City of Manchester v. Leiby, 117 F.2d 661 (1st Cir), cert. denied, 313 U.S. 562 (1941) ; Hannan v. City of Haverhill, 120 F 2d 87 (1st Cir.), cert. denied, 314 U.S. 641 (1941); Christensen v. Valentine, 122 F.2d 511 (2d Cir. 1941), rev'd, 316 U.S. 52 (1942); Oney v. Oklahoma City, 120 F.2d 861 (10th Cir. 1941); Bradford v. City of Somerset, 138 F.2d 308 (6th Cir. 1943); Ghadiali v. Delaware State Medical Soc'y, 28 F. Supp. 841 (D. Del. 1939); Joyner v. Browning, 30 F. Supp. 512 (W.D. Tenn. 1939); Bluford v. Canada, 32 F. Supp. 707 (W.D.Mo. 1940) ; Favors v. Randall, 40 F. Supp. 743 (E.D.Pa. 1940); Thomas v. Hibbets, 46 F. Supp. 368 (M.D. Tenn. 1942); Lopez v. Seccombe, 71 F. Supp. 769 (S.D. Cal. 1944).

99307 U.S. at 531 .

100 See, e.g., Christensen v. Valentine, supra note 98 (right to distribute handbills advertising submarine); Ghadiali v. Delaware State Medical Soc'y, supra note 98 (right to deliver free medical lectures); Miller v. Rivers, 31 F. Supp. 540 (M.D. Ga.), rev'd, 112 F.2d 439 (5th Cir. 1940) (right to retain office of state highway commissioner); Sweeney v. Pennsylvania Public Assistance Bd., 33 F. Supp. 587 (M.D. Pa. 1940), affd, 119 F.2d 1023 (3d Cir.), cert. denied, 314 U.S. 611 (1941) (right to financial aid from the state).

101 However, a number of courts still clung to the tests set forth in Carter v. Greenhow, 114 U.S. 317 (1884), and Holt v. Indiana Mfg. Co., 176 U.S. 68 (1899), and demied relief on the grounds that plaintiff had not shown the deprivation of a federal right, Steier v. New York State Educ. Comm'n, 271 F.2d 13 (2d Cir. 1959), cert. denied, 361 U.S. 966 (1960) (privilege of attending state college is not a federal right); Emmons v. Smith, 149 F.2d 869 (6th Cir. 1945) (no federal right to practice law); Rozelle v. Quinn, 47 F. Supp. 740 (S.D. Cal. 1942) (privileges of veterans of World War I are not within the "privileges and immumities" clause of the fourteenth amendinent), or that plaintiff had only shown the impairment of a contractual obligation, Pudlick v. Public Serv. Co., 166 F. Supp. 921 (D. Colo. 1958), or an economic right, Island Steamship Lines, Inc. v. Glennon, 178 F. Supp. 292 (D. Mass. 1959), or a property interest, Reiling v. Lacy, 93 F. Supp. 462 (D. Md. 1950); Minor v. City of Keokuk, 92 F. Supp. 833 (S.D. Iowa 1950).

102 One district court was not willing to redress a deprivation of the right to grow chinwhiskers, however. Barnes v. Atlanta Transit Sys., 144 F. Supp. 156 (N.D. Ga. 1956).

$10381 \mathrm{~S}$. Ct. at 476. 
facts constituting a deprivation ... of a right assured them by the Fourteenth Amendment they have brought themselves within [\$1983]."104

The language of both the majority and dissenting opinions would seem to make no distinction between property rights, civil rights,and rights inherently incapable of a money valuation. The Court did not mention Greenhow ${ }^{105}$ or Holt, ${ }^{106}$ and Hague $^{107}$ is ignored by all but Justice Frankfurter, who merely cites to it. ${ }^{108}$ As a result of the Monroe decision, it seems unlikely that the district courts can avoid becoming forums for litigating every invasion of personal or property interests alleged to be a denial of due process. ${ }^{109}$ The fourteenth amendment does not distinguish between the interests entitled to due process and those that are not, nor does the langnage of sections 1343 (3) or 1983. In many instances, a denial of due process will be little more than an ordinary tort. ${ }^{110}$ The deprivation of a person's right to be free from arrest without a warrant, for example, may also include the torts of trespass to property, invasion of privacy, false arrest, and assault and battery, as it did in the Monroe case. In fact, long before the Supreme Court's decision in Monroe, plaintiffs had frequently used the rubric "denial of due process" as a means of litigating their tort claims in the federal courts under section 1983.111

Unlike many of the lower courts, ${ }^{112}$ the Supreme Court did not limit redress to instances of an intentional deprivation of plaintiff's federal rights. All the Justices agreed that liability was to attach to the "natural consequences"113 of defendant's

104 Id. at 494 .

105 See text at notes $88-89$ supra.

106 See text at note 90 supra.

107 See text at notes 91-100 supra.

$10881 \mathrm{~S}$. Ct. at 494.

109 They already are, to some extent. See, e.g., Wall v. King, 206 F.2d 878 (1st Cir. 1953) (denial of driver's bense), cert. denied, 346 U.S. 915 (1953); Webb v. State Univ. of N.Y., 125 F. Supp. 910 (N.D.N.Y. 1954) (right of fraternity to affliate with national organization); Howard v. Ladner, 116 F. Supp. 783 (S.D. Miss. 1953) (right of politieal party to retain its name), rev'd, 347 U.S. 910 (1954); Pyeatte v. Board of Regents, 102 F. Supp. 407 (W.D. Okla. 1951), aff'd, 342 U.S. 936 (1952) (per curiam) (interference with business of operating boarding house for graduate students).

110 Many federal courts have recognized the similarity between an alleged denial of due process and an ordinary tort. See, e.g., Dimeen v. Williams, 219 F.2d 428 (9th Cir. 1958) (false imprisonment); Yglesias v. Gulfstream Park Racing Ass'n, 201 F.2d 817 (5th Cir. 1953) (false imprisonment); Viles v. Symes, 129 F.2d 828 (10th Cir.), cert. denied, 317 U.S. 633 (1942) (malicious prosecution, false imprisonment); Arkansas v. Central Sur. \& Ins. Corp., 102 F. Supp. 444 (W.D. Ark. 1952) (assault and battery, false imprisonment).

111 State of Arkansas v. Godbehere, 216 F.2d 623 (8th Cir. 1958) (personal injuries resulting from use of unreasonable force in making an arrest without a warrant or probable cause); Jackson v. Duke, 259 F.2d 3 (5th Cir. 1958) (assault and battery, false imprisonment); Coleman v. Johnson, 247 F.2d 273 (7th Cir. 1957) (negligence); Mohler v. Miller, 235 F.2d 153 (6th Cir. 1956) (false arrest); Lewis v. Brautigan, 227 F.2d 124 (5th Cir. 1952) (brutality in extracting a confession); Geach v. Moynahan, 207 F.2d 714 (7th Cir. 1953) (same); Davies v. Turner, 197 F.2d 847 (5th Cir. 1952) (false arrest, false imprisonment, assault and battery); Watkins v. Oklahoma Country Club, 183 F.2d 440 (8th Cir. 1950) (false arrest, false imprisonment); McShane v. Moldovan, 172 F.2d 1016 (6th Cir. 1949) (false arrest, false imprisonment, malicious prosecution); Haifetz v. Rizzo, 178 F. Supp. 828 (E.D.Pa. 1959) (false arrest, false imprisonment, destruction of business); Davis v. Jolunson, 138 F. Supp. 572 (N.D. Ill. 1955) (wrongful death); Kenny v. Killian, 133 F. Supp. 571 (W.D. Mich. 1955), affd, 232 F.2d 288 (6th Cir.), cert. denied, 352 U.S. 855 (1956) (illegal detention).

112 See, e.g., Simons v. Whitaker, 252 F.2d 224 (5tl Cir. 1958) ; Cobb v. City of Malden, 202 F.2d 701 (1st Cir. 1953); Diggs v. Pennsylvania PUC, 180 F.2d 623 (3d Cir. 1950); Bottone v. Lindsley, 170 F.2d 705 (10th Cir. 1948); Kenny v. Hatfield, 132 F. Supp. 814 (W.D. Mich. 1955), aff'd, 232 F.2d 288 (6th Cir.), cert. denied, 352 U.S. 856 (1956); Dye v. Cox, 125 F. Supp. 714 (E.D. Va. 1954).

11381 S. Ct. at $484,487,494$. 
acts, whether or not those consequences were intended. In the words of Justice Frankfurter, "allegations that respondents in fact did the acts which constituted violations of constitutional rights are sufficient."114 Justice Douglas said that section 1983 "should be read against the background of tort liability that makes a man responsible for the natural consequences of his acts." at face value, seems to impose strict liability for the violation of constitutional or statutory rights. ${ }^{116}$ The words "natural consequences" refer not to causes, but to effects. In this light, even neghigence or a mistake of law can give rise to a cause of action under section 1983, as where a judge erroneously admits in evidence a coerced confession, which admission is later lield to be a demal of due process. ${ }^{117}$ The development of the doctrine of immunity, discussed earlier, ${ }^{118}$ was a direct attempt to avoid liability $m$ these circumstances.

It was further to reduce the impact of section 1983 that most lower federal courts had required the plaintiff to allege and prove a specific intent to violate his federal rights. ${ }^{110}$ They were apprehensive that every local official might be subjected to a "second guess" in the district courts whenever it could be alleged that his acts somehow infringed plaintiff's constitutional or statutory rights. ${ }^{120} \mathrm{But}$, as pointed out by Justice Frankfurter, the requirement of a specific intent had little practical effect, since it often caine to little more than a finding that the defendant had acted intentionally and "without justification to bring about the circumstances which infringe[d] plaintiff's rights." 121 Nor was it demanded by the language of section 1983, which nowliere mentions even willful conduct. Nevertheless, the necessity of finding a specific intent did represent an attempt to keep federal power within some bounds lest "all matters formerly within the exclusive cognizance of the states should become matters of national concern." 122

Whether the "natural consequences" test also apphes to a denial of equal protection poses a more difficult problem. The Supreme Court did not specifically limit the instances in which this test is to be apphed. It said that "allegations of facts constituting a deprivation ... of $a$ right guaranteed by the Fourteenth Amendment"123 satisfy the requirements of section 1983. Since section 1983 does not require a specific intent, an argument could be made that the plaintiff need not allege the defendant intentionally discriminated against him. Under the natural consequences test, any discretionary act conferring a benefit or imposing a penalty upon one person rather than another, who is similarly situated, results in a deprivation of plaintiff's right to equal treatment under the law.

114 Id. at 495 .

115 Id. at 484.

116 In Cobb v. City of Malden, 202 F.2d 701 (1st Cir. 1953), Judge Magruder said that $\$ 1983$ "creates a new federal tort, where all that has to be proved is that the defendants, as a result of their conduct under state law, have in fact caused harm to the plaintiff by depriving him of rights, etc., secured by the Constitution of the United States." Id. at 706.

117 But see Agnew v. City of Compton, 239 F.2d 226 (9th Cir. 1956) ("No one has a constitutional right to be free from a law officer's honest misunderstanding of the law or facts in making an arrest." Id. at 231); Diggs v. Pennsylvania PUC, 180 F.2d 623 (3d Cìr. 1950).

118 See note 80 suppra.

119 Cases cited note 112 supra.

120 See, e.g., McGuire v. Todd, 198 F.2d 60 (5th Cir.), cert. denied, 344 U.S. 835 (1952).

$121 \mathrm{~S}$. Ct. at 494-95.

122 Charlton v. City of Hialeah, 188 F.2d 421, 423 (5th Cir. 1951).

$12381 \mathrm{~S}$. Ct. at 476. (Emphasis added.) 
This argument, however, ignores Snowden v. Hughes, ${ }^{124}$ where the Supreme Court said:

[N] ot every denial of a right ... . involves a denial of the equal protection of the laws, even though the denial ... to one person may operate to confer it on another .... [A]n erroneous or mistaken performance of the statutory duty, although a violation of the statute, is not without more a denial of the equal protection of the laws.

The unlawful administration by state officers of a state statute fair on its face, resulting in its unequal application to those who are entitled to be treated alike, is not a denial of equal protection unless there is shown to be present in it an element of intentional or purposeful discrimination. This nuay appear on the face of the action taken with respect to a particular class or person, ... or it may only be shown by extrinsic evidence showing a discriminatory design to favor one individual or class over another not to be inferred from the action itself . . . . But a discriminatory purpose is not presumed ... ; there inust be a showing of "clear and intentional discrinination"... 125

The Court in Monroe did not mention Snowden v. Hughes, nor did it place its decision on the ground of a denial of equal protection. ${ }^{128}$ The Court's language, though broad, could be limited to instances where the plaintiff alleges a denial of the right to due process. And it should be so limited, for otherwise every inadvertent or unintentional distinction between persons or classes of persons arising from the administration of state law could give rise to a suit for damages.

As in the case of a denial of due process, however, it seems unlikely that the Supreme Court will make distinctions based upon the nature of the underlying interest where the plaintiff alleges a deprivation of his right to equal protection. Whether that interest be characterized as personal, political, or in the nature of a property right, the injury in each case rests not so much upon the harm to it, but in the fact that the plaintiff has been treated with an unequal hand. The right to equal protection is a specific and independent right apart from the interest affected. ${ }^{127}$ The plaintiff does not seek to redress the unfair treatment of some other interest, but seeks only to enforce his own personal right to equality. This is unlike a denial of due process, where the cause of action depends upon harm to something else, such as a business or the right to be free from an unreasonable search and seizure.

In general, the lower federal courts have had no difficulty in assuming jurisdiction of suits to redress a denial of equal protection. ${ }^{128}$ The nature of the underlying interest has not given rise to a rash of distinctions. ${ }^{129}$ Discriminatory treat-

124321 U.S. 1 (1944).

126 Id. at 8 .

$126 \mathrm{~S}$. Ct. 2t $495 \mathrm{n} .8$.

127 See, e.g., Glicker v. Michigan Liquor Control Comm'n, 160 F.2d 96 (6th Cir. 1947).

128 But cf. Dawley v. City of Norfolk, 159 F. Supp. 642 (E.D. Va.), aff'd, 260 F.2d 647 (4th Cir. 1958), where it was held that the word "colored" on lavatory doors in a state courthouse did not imply that Negro attorneys were inferior to white attorneys.

129 The courts have usually assumed jurisdiction regardless of the nature of the underlying interest. See, e.g., Brooks v. School Dist. of City of Moverly, 267 F.2d 733 (8th Cir.), cert. denied, 361 U.S. 894 (1959) (right to retain employment) ; McCoy v. Providence Journal Co., 190 F.2d 760 (1st Cir. 1951) (right of access to public records) ; Burt v. City of New York, 156 F.2d 791 (2d Cir. 1946) (application for building permit); Johnson v. Yeilding, 165 F. Supp. 76 (N.D. Ala. 1958) (right to take examination for eniployment as city police officer); Tonkins v. City of Greensboro, 162 F. Supp. 549 (N.D.N.C. 1958), aff'd, 276 F.2d 890 (4th Cir. 1960) (right to use public swimming pool); Brown v. Ritter, 179 F. Supp. 679 (W.D. Ky. 1956) (right to sit on jury); Fayson v. Beard, 134 F. Supp. 379 (E.D. Tex. 1955) (right to use city parks) ; Vann v. Toledo Metropohtan Housing Authority, 113 F. Supp. 210 (N.D. Ohio 1953) (right to occupancy of public housing facilities); John v. Board of Trustces, 83 F. Supp. 707 (E.D. Ky. 1949) (right to be admitted to state graduate school). 
ment has been considered just as much an infringement of plaintiff's rights when he has been barred from the public swimming pool ${ }^{130}$ or municipal golf course, ${ }^{131}$ as when he has been deprived of the right to vote. ${ }^{132}$ The lower courts, in the inain, have treated denials of equal protection as sui generis and have generally found jurisdiction under section 1343 (3) whenever the plaintiff las alleged intentional discrimination. ${ }^{133}$ Jurisdiction has not been limited to sunts alleging unequal treatment because of race or color, ${ }^{134}$ but has been extended to actions to redress a denial of equal protection for any reason, as where a bar owner complains that the state hiquor commission has singled her out and revoked her liquor permit for political reasons, ${ }^{135}$ or where a voter alleges that he was not allowed to register because of the registrar's grudge against his brother. ${ }^{136}$

It is in the field of equal protection that sections $1343(3)$ and 1983 fulfill their most important function, for here they work to provide a federal remedy, in the federal courts, for the deprivation of a personal right which might otherwise be without means of civil redress. Unlike a denial of due process, which can often be characterized as an ordinary tort, ${ }^{137}$ discriminatory treatunent does not give rise to a cause of action for tort or otherwise, unless it is perchance accompanied by violence or other tortious conduct. In itself, the right to equality exists separate and apart from the interest infringed and is actionable only insofar as Congress makes it actionable. Thus, if the Third Civil Rights Act were intended to provide a means of securing those rights guaranteed by the fourteenth amendinent, as the Court in Monroe said it was, ${ }^{138}$ there can be little quarrel with an interpretion of sections 1343 (3) and 1983 which finds in a denial of equal protection a cause of action where before there had been none.

\section{B. Action Under Color of any State Law, Statute, Ordinance, Regulation, Custom, or Usage}

The plaintiff cannot invoke federal jurisdiction under section 1343 (3) merely by alleging the deprivation of a right, privilege, or immunity secured by the Constitution or by laws providing for equal rights. To state a claim within the jurisdiction of the court, he inust also allege that the deprivation was caused by persons acting under color of state law. ${ }^{\mathbf{1 3 9}}$

130 Tonkins v. City of Greensboro, 162 F. Supp. 549 (N.D.N.C. 1958), aff'd, 276 F.2d 890 (4th Cir. 1960).

181 Beal v. Holcombe, 193 F.2d 384 (5th Cir. 1951); Holmes v. City of Atlanta, 124 F. Supp. 290 (N.D. Ga. 1954), aff'd, 223 F.2d 93 (5th Cir. 1955).

132 Smith v. Allwright, 321 U.S. 649 (1943); Mitchell v. Wright, 154 F.2d 724 (5th Cir. 1946).

133 See, e.g., Hoffman v. Halden, 268 F.2d 280 (9th Cir. 1959); Agnew v. City of Compton, 239 F.2d 226 (9th Cir.), cert. denied, 353 U.S. 959 (1957) ; Burt v. City of New York, 156 F.2d 791 (2d Cir. 1946); Shoate v. Howery, 130 F. Supp. 879 (E.D. Okla. 1955); Dyer v. Kazuhisa ABE, 138 F. Supp. 220 (D. Hawaii 1956), rev'd, 256 F.2d 728 (9th Cir. 1958).

134 See note 129 supra.

135 Glicker v. Michigan Liquor Control Comm'n, 160 F.2d 96 (6th Cir. 1947).

136 Tullier v. Giordano, 265 F.2d 1 (5th Cir. 1959).

187 See cases cited notes 110-11 supra.

138 See text at notes 103-04 supra.

139 The provisions of the Civil Rights Acts do not apply to federal officials, since they do not act under color of state law in exercising the power conferred upon them by Congress. Heyward v. Public Housing Administration, 238 F.2d 689 (5th Cir. 1956) (federal agency acting in concert with state officials); Insular Police Coinun'n v. Lopez, 160 F.2d 673 (1st Cir.), cert. denied, 331 U.S. 855 (1947) (officials of insular government); Viles v. Symes, 129 F.2d 
It is here that Monroe v. Pape once again assumes historic proportions, for the Court held, Justice Frankfurter dissenting, that "actions under color of state law" include even the illegal acts of state officials, as long as they purport to be discharging the duties of their offices in causing injury to the plaintiff. ${ }^{140}$ Justice Frankfurter, arguing from legislative history, would have drawn a distinction between unconstitutional acts authorized by state law and those unauthorized, holding the latter beyond the reach of civil redress under section $1983 .{ }^{141}$ In a separate opinion concurring with the majority, Mr. Justice Harlan, joined by Mr. Justice Stewart, attacked Justice Frankfurter's position as unwarranted by legislative history or by an analysis of the purposes of the Civil Rights Acts. ${ }^{142}$ As in most cases of attempting to find the epheineral "intent" of Congress, here an intent existing ninety years ago, neither side can claim a clear victory. The majority, however, had the support of its earlier decisions in United States v. Classic ${ }^{148}$ and Screwes v. United States, ${ }^{144}$ wherem it had held that one may act under color of state law even though he acts illegally. Likewise, the same position has been fairly consistently adopted by the district courts and courts of appeal in finding state action within the meaning of sections 1983 and $1343(3) .145$

If any argument is to be drawn from history, it would seem to support the majority. The Civil Rights Acts were enacted in an era when Congress was taking strong and obvious measures to reach those forms of state activity which would seek to restore the old order in the South. ${ }^{146}$ The greatest threat to the rights of the Negro and his sympathizers came not from legislative enactments, but from the "grass roots" of state resistance-the sheriff, the magistrate, or any one of a number of local officials with whom these persons could be expected to be in daily contact. To require that this grass roots campaign be conducted pursuant to express state authority for purposes of sections 1343 (3) and 1983 would have been to ignore reality. Such authorization would have been clearly unconstitutional under the fourteenth amendment and would have been met head on by the act of $1866,{ }^{147}$ which was enacted to combat the "Black Codes" and other forms of legalized dis-

828 (10th Cir.), cert. denied, 317 U.S. 633 (1942) (federal judge, United States Attorney, witness in a federal court); Payne v. McKee, 153 F. Supp. 932 (E.D. Va. 1957) (admiral); Fischler v. McCarthy, 117 F. Supp. 643 (S.D.N.Y. 1954), aff'd, 218 F.2d 164 (2d Cir. 1959) (United States Senator); Swanson v. Willis, 114 F. Supp. 434 (D. Alaska 1953), aff'd, 220 F.2d 440 (9th Cir. 1955) (deputy U.S. marshal); Shimola v. Local Bd. No. 42, 40 F. Supp. 808 (N.D. Ohio 1941) (menibers of draft board).

14081 S. Ct. at 484.

141 Id. at 497 .

142 Id. at 486 .

143313 U.S. 299 (1941).

144325 U.S. 91 (1945).

145 See, e.g., Geach v. Moynahan, 207 F.2d 714 (7th Cir. 1953); Valle v. Stengel, 176 F.2d 697 (3d Cir. 1949); McShane v. Moldovan, 172 F.2d 1016 (6th Cir. 1949); Westminster School Dist. v. Mendez, 161 F.2d 774 (9th Cir. 1947) ; Burt v. City of New York, 156 F.2d 791 (2d Cir. 1946) ; Picking v. Pennsylvania R.R., 151 F.2d 240, rehearing denied, 152 F.2d 753 (3d Cir. 1945); Williams v. Kansas City, 104 F. Supp. 848 (W.D.Mo. 1952), af'd, 205 F.2d 47 (8th Cir. 1953). Contra, DeLoach v. Rogers, 268 F.2d 928 (5th Cir. 1959) ; Hallmark Prods. v. Mosley, 190 F.2d 904 (8th Cir. 1951); Snowden v. Hughes, 132 F.2d 476 (7th Cir. 1943), aff'd 321 U.S. 1 (1944); Jones v. Oklahoma City, 18 F.2d 860 (10th Cir. 1935).

146 This aspect of the Third Civil Rights Act is authoritatively discussed by Justice Douglas in Monroe v. Pape, 81 S. Ct. at 476-84. See generally, Randald, The Crvil War and ReconSTRUCTION (1937).

14714 Stat. 27 (1866). 
crimination. ${ }^{148}$ Therefore, if Congress were to reach those acts which portended the greatest harm to the cause of civil rights, it would have had to provide redress against local officials whenever they used the powers of their offices to strike back, whether or not their acts were legal under the "letter" of state law.

In holding that the Chicago policemen acted under color of state law, the Supreme Court in Monroe also eliminated the contention that state action does not include the acts of mumicipal and other officials. Prior to this time, several of the lower courts lad apparently felt they could find state action only where the defendant exercised power directly conferred by the state, intimating that power received indirectly, as through a city or county, would not be sufficient to bring his actions under color of state law. ${ }^{149}$ This was never the rule of a majority of the federal courts, lowever. ${ }^{150}$

Acts done for purely personal reasons, on the other hand, as where a police officer suddenly turns upon and strikes a Negro awaiting registration as a voter because he "does not approve of Negroes voting,"151 are not considered "acts under color of state law" within the meaning of section 1983.152 Nevertheless, the Supreme Court lias mdicated that it is willing to go a long way to find state action in civil rights cases. In Screws v. United States, ${ }^{153}$ for example, it held that a sheriff acted under color of state law when he joined with others in beating a prisoner to death, even though "there was evidence that Screws [the slieriff] held a grudge against Hall [the prisoner] and had threatened to 'get' him."154

Different problems arise where the acts of private citizens are leld to be under color of state law. ${ }^{165}$ For one thing, the language of section 1343 (3) makes it clear that jurisdiction is not to extend to the acts of private persons. ${ }^{156}$. For another,

148 See generally Poole, Statutory Remedies for the Protection of Civil Rights, 32 ORE. L. REv. 210 (1953) ; Gressman, The Unhappy History of Civil Rights Legislation, 50 MICH. L. REv. 1323 (1952).

149 See, e.g., Jones v. Oklahoma City, 78 F.2d 860 (10th Cir. 1935); Browder v. Gayle, 142 F. Supp. 707 (M.D. Ala. 1956); Williams v. Kansas City, 104 F. Supp. 848 (N.D. Mo. 1952), aff'd, 205 F.2d 47 (8th Cir. 1953); Whitmyer v. Lincoln Parish School Bd., 75 F. Supp. 686 (W.D. La. 1948) ; Davis v. Cook, 55 F. Supp. 1004 (N.D. Ga. 1944), aff'd, 178 F.2d 595 (5th Cir. 1949), cert. denied, 340 U.S. 811 (1950).

150 See, e.g., Brooks v. School Dist. of City of Moberly, 267 F.2d 733 (8th Cir. 1959); Jackson v. Duke, 259 F.2d 3 (5th Cir. 1958); Coleman v. Johnson, 247 F.2d 273 (7th Cir. 1957); Mohler v. Miller, 235 F.2d 153 (6th Cir. 1956); Nelson v. Knox, 230 F.2d 483 (6th Cir. 1956); Mueller v. Powell, 203 F.2d 797 (8th Cir. 1953); Westminster School Dist. v. Mendez, 161 F.2d 774 (9th Cir. 1947) ; Haifetz v. Rizzo, 171 F. Supp. 654 (E.D. Pa. 1959) ; Johnson v. Yeilding, 165 F. Supp. 76 (N.D. Ala. 1958); Brown v. Rutter, 139 F. Supp. 679 (W.D. Ky. 1956) ; Davis v. Johnson, 138 F. Supp. 572 (N.D. IIl. 1955); Lopez v. Seccombe, 71 F. Supp. 769 (S.D. Cal. 1944); Thomas v. Hibbets, 46 F. Supp. 368 (M.D. Tenn. 1942).

101 Brown v. City of Wisner, 122 F. Supp. 736, 737 (W.D. La. 1954).

152 Cf. Deloach v. Rogers, 268 F.2d 928 (5th Cir. 1959).

163325 U.S. 91 (1945).

154 Id. at 93 .

105 Indian tribal councils are treated as private organizations and are not subject to suit under $\S 1983$, since they do not act under color of state law in exercising their governmental powers. Toledo v. Pueblo De Jemez, 119 F. Supp. 429 (D.N.M. 1954).

150 A remote connection with the state, or with authority conferred by the state, will not suffice to bring the acts of a private person or corporation under color of state law. See, e.g., Eaton v. Board of Managers of James Walker Nemorial Hosp., 261 F.2d 521 (4th Cir. 1958), cert. granted, 359 U.S. 984 (1959) (private hospital built on land given by city and receiving payments froin city for treatment of certain patients); Dinwiddie v. Brown, 230 F.2d 465 (5th Cir.), cert. denied, 352 U.S. 861 (1956) (use of civil proceedings to foreclose deed of trust and try title); Williams v. Yellow Cab Co., 200 F.2d 302 (3d Cir. 1952) (umion empowered by state to act as exclusive representative of its members); Shemantis v. Froemcke, 189 
there is a grave constitutional question whether the provisions of the Civil Rights Acts can apply at all to individuals not acting in an official capacity. In Collins $v$. Hardyman, ${ }^{157}$ the Supreine Court questioned Congress's power "under and apart from the Fourteenth Amendment"158 to subject private persons to civil redress in a federal court, or in any court, under the Civil Rights Acts. The decision, however, was placed on other grounds. ${ }^{159}$

In at least two fact situations it has been held that the complaint states a claim within the jurisdiction of the district court under section 1343(3) where a private citizen is the defendant. The first situation is one where a state statute makes a person an agent of the state for a particular purpose, as in Fleming v. South Carolina Elec. \& Gas Co. ${ }^{160}$ In that case a statute commanded bus drivers to segregate their passengers according to race. Allegations that the driver acted under color of state law were deemed sufficient to confer jurisdiction upon the district court in an action brought against his employer, a privately owned bus company. ${ }^{161}$

To subject an enterprise to federal control and civil liability by virtue of a nonconsensual agency would seem to be an unwarranted extension of sections 1343 (3) and 1983, particularly when violation of the state statute is a criminal offense. ${ }^{108}$ This is not a situation where a person wilhngly seeks public office and then proceeds to infringe upon the rights of others in exercising the powers of that office. Rather, it is a case of a person being compelled by law to act in a particular manner. The defendant is simply obeying a law made applicable to him. While his acts may impinge upon plaintiff's civil rights, they should not be deemed "state action" as long as they are merely private acts in obedience to state law. Yet, if Justice Frankfurter's analysis of state action in Monroe v. Pape ${ }^{183}$ were to be followed, such acts would unquestionably be considered done under color of state law, since they would be specifically authorized, indeed compelled, by the statute. The majority, however, has left itself some room to adjust the equities in these situations by indicating that it will look at the facts of each case to see whether or not the defendant can properly be considered an agent of the state. ${ }^{104}$

F.2d 963 (7th Cir. 1951) (creditor apparently using self-help to remove personal belongings of debtor); Campo v. Niemeyer, 182 F.2d 115 (7th Cir. 1950) (attorney and client conspiring to deprive plaintiff of property through judicial foreclosure); Davidson v. Lachman Bros. Inv. Co., 76 F.2d 186 (9th Cir. 1935) (use of judicial process to foreclose deed of trust); Johnson v. Levitt \& Sons, 131 F. Supp. 114 (E.D. Pa. 1955) (housing project operator subject to control of various state agencies and officials and alleged to have assumed duties of municipabity in constructing streets, schools, sewers, and water systems for his projects); Norris v. Mayor \& City Council of Baltimore, 78 F. Supp. 451 (D. Md. 1948) (private sclool receiving public funds for scholarships). Cf. Central Ice Cream Co. v. Golden Rod Ice Cream Co., 153 F. Supp. 684 (N.D. Ml. 1957), rev'd, 257 F.2d 417 (7th Cir. 1958) (defendant threatening to harm plaintiff's business by persisting to bid for a contract to supply ice cream for school lunches).

157341 U.S. 651 (1951).

$158 I d$. at 659 .

159 The Court held that defendants' acts were not aimed at denying plaintiffs equal protection of the laws or equal privileges and immunities, and did not reach the issue of state action. $I d$. at $660-63$.

160224 F.2d 752 (4th Cir. 1955) (per curiam).

101 Cf. Baldwin v. Morgan, 251 F.2d 780 (5th Cir. 1958) ; Solomon v. Pennsylvania R.R., 96 F. Supp. 709 (S.D.N.Y. 1951) ; Browder v. Gayle, 142 F. Supp. 707 (M.D. Ala.), aff'd, 352 U.S. 903 (1956) (dictum).

162 In Fleming v. South Carolina Elec. \& Gas Co., 224 F.2d 752 (4tl, Cir. 1955) (per curiam), refusal to comply with the statute was a misdemeanor. S.C. CODE \& 58-1491 (1952).

$16381 \mathrm{~S}$. Ct. at 497.

104 See the Court's discussion of action "under color of state law" id. at 476-84. 
The second instance in which the federal courts have found a private citizen acting under color of state law is where he is alleged to have conspired with a state official to deprive the plaintiff of his federal rights. ${ }^{165}$ State action in effect rubs off on the parties to the conspiracy and subjects them to the jurisdiction of the district court. ${ }^{166}$ In Hoffman $v$. Halden, ${ }^{167}$ for example, the Ninth Circuit recently sustained a finding of jurisdiction under section $1343(3)$ where it was alleged that the defendants, one of whom was a private citizen, conspired with county health officials to imprison plaintiff in a mental hospital without due process of law. ${ }^{168}$

In Monroe the question of a conspiracy evidently was not before the Court, although it could have been alleged that defendant police officers conspired to deprive plaintiffs of their federal rights. ${ }^{169}$ Even so, the Court would not have been called upon to decide whether a civil conspiracy may be used to link private persons to official wrongs, since all the individual defendants purported to act as agents of the city of Chicago.

The net effect of bringing private acts under color of state law through allegations of a conspiracy is to enable the plaintiff to proceed against a number of persons not otherwise subject to federal jurisdiction under section $1343(3) .{ }^{170} \mathrm{It}$ also permits the district courts to expand their jurisdiction over state tort actions, such as an action for malicious prosecution where the defendant is alleged to have conspired with a state official to employ legal proceedings to harass or otherwise injure the plaintiff in violation of his right to due process. ${ }^{171}$

The use of a conspiracy to find that a private citizen acted under color of state law may be curtailed by a greater insistence that the deprivation of rights be alleged to have been caused by him. ${ }^{172}$ In the past federal courts have generally been unwilling to assume jurisdiction under section 1343(3) where it could not reasonably be shown that the acts of the defendant were the proximate cause of the wrong sought to be redressed.173 For example, at least one court has refused to assume jurisdiction of a suit agamst an attorney who filed the complaint in a proceeding to commit the plaintiff to a mental institution, on the ground that

165 See, e.g., Hoffman v. Halden, 268 F.2d 280 (9th Cir. 1959) ; Baldwin v. Morgan, 251 F.2d 780 (5th Cir. 1958); Picking v. Pennsylvania R.R., 151 F.2d 240, rehearing denied, 152 F.2d 753 (3d Cir. 1945). Cf. Arkansas v. Central Sur. \& Ins. Corp., 102 F. Supp. 444 (W.D. Ark. 1952) ; Llano Del Rio Co. of Nevada v. Anderson-Post Hardwood Lumber Co., 79 F. Supp. 382 (W.D. La. 1948).

$100 C f$. Picking v. Pennsylvania R.R., 151 F.2d 240, 249, rehearing denied, 142 F.2d 753 (3d Cir. 1945).

167268 F.2d 280 (9th Cir. 1959); noted, 58 Micr. L. Rev. 786 (1960).

168 In Baldwin v. Morgan, 251 F.2d 780 (5th Cir. 1958), it was held that those who directly assist a state agency in carrying out the unlawful action become a part of it and subject to civil redress under $\$ 1983$. A fortiori, they are subject to the jurisdiction conferred upon the district courts by $\$ 1343(3)$.

${ }_{169}$ A passing mention of a civil conspiracy under $\S 1983$ may be found in the opinion of Justice Frankfurter. His statements are imconclusive, however. $81 \mathrm{~S}$. Ct at 522.

170 See text at note 156 supra.

171 McShane v. Moldovan, 172 F.2d 1016 (6th Cir. 1949). But cf. Cuiksa v. City of Mansfield, 250 F.2d 700 (6th Cir. 1957), cert. denied, 356 U.S. 937 (1958).

172 This would be in harmony with the language of $\S 1983$, which speaks of the defendant as the "person who ... subjects or causes to be subjected any citizen ... . or other person ... to the deprivation of any rights, privileges, or immunities ..." See text at notes 73-74 supra. 173 See, e.g., Cuiksa v. City of Mansfield, 250 F.2d 700 (6th Cir. 1957); Whittington v. Johnston, 201 F.2d 810 (5th Cir.), cert. denied, 346 U.S. 867 (1953); Island Steaniship Limes v. Glennon, 178 F. Supp. 292 (D. Mass. 1959); Grubbs v. Slater, 144 F. Supp. 554 (W.D. Ky. 1955). 
the filing of the complaint was not the proximate cause of the ensuing illegal confinement, ${ }^{174}$ even though the attorney was an officer of the court and, arguably, a state officer. ${ }^{175}$ Analogous to the attorney is the private citizen who plays a passive or merely incidental role in a conspiracy with a state official, where it is the acts of the latter that deprive the plaintiff of his federal rights.170

When the private citizen actively carries out the purpose or object of the conspiracy, however, and it is the state official who remains passive, the former's acts may well be the cause of plaimtiff's injury. ${ }^{177}$ Nevertheless, it is arguable that they are not done under color of state law. The private person is not using, or misusing, power conferred upon him as a state official, although he could be said to be acting as an agent of his co-conspirator, who is clothed with the authority of the state..$^{178}$

Finding state action by means of a civil conspiracy can conceivably be limited to those situations where both the private citizen and the state officer take an active part in inflicting an injury upon the plaintiff. ${ }^{172}$ The dual requirements of proximate cause and state action would then be satisfied, with the conspiracy serving to bring the acts of the private citizen under color of state law. Whether the use of a conspiracy to find jurisdiction under section $1343(3)$ will be so restricted remains to be seen.

Apart from questions of civil conspiracies and statutes making the defendant an agent of the state, state action may also be found where a private citizen voluntarily exercises a common-law or statutory right, such as the right to make a citizen's arrest. ${ }^{180}$ Here he would become, in effect, a temporary official of the state, acting on its behalf to preserve peace and order. Since he claims to act on behalf of the state, it would seem logical that he be subjected to the same liabilities as any other state officer. ${ }^{181}$ Thus, the person arrested may well be able to assert a claim against him in the federal courts under section 1983, when in making the arrest he deprives the plamtiff of his federal rights, privileges, or immunities.

174 Whittington v. Johnson, 201 F.2d 810 (5th Cir.), cert. denied, 346 U.S. 867 (1953).

175 The courts have refused to hold that an attorney is a state officer where the plaintiff seeks redress under $\$ 1983$. E.g., Bottone v. Lindsley, 170 F.2d 705 (10th Cir. 1958); Grubbs v. Slater, 144 F. Supp. 554 (W.D. Ky. 1955). Cf. Moffett v. Commerce Trust, 187 F.2d 242 (8th Cir. 1951) (use of state courts in administration of estate).

${ }^{170} \mathrm{Cf}$. Hoffman v. Halden, 268 F.2d 280 (9th Cir. 1959), where it was held that the acts of a person immune from surit under $\$ 1983$ cannot be used against those who are not immune. But see Walker v. Bank of America, 268 F.2d 16 (9th Cir.), cert. denied, 361 U.S. 403, rehearing dentied, 361 U.S. 941 (1959), indicating that a private person may be subject to redress under $\S 1983$ where it is the acts of a co-conspirator, a state officer, that cause the plaintiff to be deprived of his rights.

${ }^{177}$ A state officer, immune from suit under $\$ 1983$, does not loose his immunity by virtue of a conspiracy with a person or persons not immune from suit. Baldwin v. Morgan, 251 F.2d 780 (5th Cir. 1958).

178 "If sufficient allegations appear of the acts of one defendant among the conspirators, causing damage to the plaintiff, and the act of the particular defendant was done pursuant to the conspiracy, during its course, in furtherance of the objects of the conspiracy with the requisite purpose and intent and under color of state law, then all the defendants are liable for the acts of the particular defendant under the general principles of agency on which conspiracy is based." Hoffman v. Halden, 268 F.2d 280, 295 (9th Cir. 1959) (dictum).

170 Cf. Robinson v. Fanelli, 94 F. Supp. 62 (S.D.N.X. 1950).

${ }^{180}$ See generally Perkins, Crominal Law 869-73 (1957).

181 Cf. Rice v. Elmore, 165 F.2d 387 (4th Cir. 1947) (person may be state official de facto, if not de jure). See also the statement of the court in Walker v. Bank of Amcrica Nat'l Trust \& Sav. Ass'n, 268 F.2d 16 (9th Cir.), cert. denied, 361 U.S. 903, rehearing denied, 361 U.S. 941 (1959): "A person does not act under color of state law unless he acts, or purports to act, on behalf of the state as a state official." (Emphasis added.) Id. at 24. 
A similar situation may arise when an honorary member of a sheriff's posse undertakes to aid local law enforcement officers in the apprehension of a suspected criminal. ${ }^{182}$ Here also the private citizen would seem to don the mantle of a state officer, and it could be argued that he too should be considered to act under color of state law, as long as he claims a right to act in an official capacity as a member of the posse. ${ }^{183}$

\section{CONCLUSION}

The decision in Monroe v. Pape does not revolutionize the law. It merely approves what has been going on in the district courts and courts of appeal ever since Justice Stone's 1938 opinion in Hague v. CIO.$^{184}$ But it is this approval that makes the Monroe case so important and so likely to lead to even niore litigation under section 1983. ${ }^{185}$

Although there is an adequate remedy in the state tribunals, as in Monroe, the aggrieved party will not be prevented from initiating proceedings in the federal courts. Prior to this time some of the federal courts had invoked the doctrines of abstention ${ }^{188}$ or exhaustion of state remedies ${ }^{187}$ in refusing to grant redress under section 1983. In Monroe, the Supreme Court said that "it is no answer that the State has a law which if enforced would give relief. The federal remedy is supplementary to the State and the state remedy need not be first sought and refused before the federal one is invoked."188

182 Mueller v. Powell, 105 F. Supp. 344 (W.D. Mo. 1952), aff'd, 203 F.2d 797 (8th Cir. 1953).

183 In Mueller, supra note 182, the district court reached the opposite conclusion. The issue was not raised on appeal. Mueller v. Powell, 203 F.2d 797 (8th Cir. 1953).

184 See text at notes 95-102 supra.

185 One of the advantages to be obtained by bringing suit under $\S 1983$ is that state doctrines of immunity will not preclude holding the defendant liable for damages. $81 \mathrm{~S}$. Ct. at 515. At least one court has suggested that punitive damages may also be recovered. Geach v. Olson, 211 F.2d 682 (7th Cir. 1954). By bringing suit in a federal district court, the plaintiff may find a forum more sympathetic to his claim, offering speedier relief or other procedural advantages under Federal Rules, such as the rules of civil discovery. Furthermore, whether or not a cause of action arises from, or survives, the injured party's death will be determined as a matter of federal law. See, e.g., Davis v. Johnson, 138 F. Supp. 572 (N.D. Ill. 1955).

On the other hand, the applicable statute of limitations will be that of the state wherein the cause of action arose and the district court is located. Hoffman v. Halden, $268 \mathrm{~F} .2 \mathrm{~d} 280$ (9th Cir. 1959); Mohler v. Mohler, 235 F.2d 153 (6th Cir. 1956) ; West v. Board of Educ., 165 F. Supp. 382 (D. Md. 1958); Kenny v. Killian, 133 F. Supp. 571 (W.D. Mich. 1955), aff'd, 232 F.2d 288 (6th Cir. 1956), cert. deried, 352 U.S. 855 (1956).

186 See, e.g., Cooper v. Hutchinson, 184 F.2d 119 (3d Cir. 1950) ; Catoggio v. Grogan, 149 F. Supp. 94 (D.N.J. 1957) ; Perry v. Folsom, 144 F. Supp. 874 (N.D. Ala. 1956). Cf. Chapman v. Trustees of Delaware State College, 101 F. Supp. 441 (D. Del. 1951).

187 See, e.g., Baron v. O'Sullivan, 258 F.2d 336 (3d Cir. 1958) (administrative remedies); People v. Bibb, 252 F.2d 217 (7th Cir. 1958) ("remedies"); Williams v. Dalton, 231 F.2d 646 (6th Cir. 1956) (judicial remedies) ; Davis v. Arn, 199 F.2d 424 (5th Cir. 1952) (administrative remedies); Peay v. Cox, 190 F.2d 123 (5th Cir. 1951) (administrative remedies); Wilson v. West Virginia Bd. of Embalmers \& Funeral Directors, 168 F. Supp. 753 (S.D.W.Va. 1959) (administrative remedies); Grubbs v. Slater, 144 F. Supp. 554 (W.D. Ky. 1955), aff'd sub noni. Grubbs v. Farnsley, 234 F.2d 666 (6th Cir. 1956), cert denied, 352 U.S. 894 (1956) (administrative remedies); Remmy v. Smith, 102 F. Supp. 708 (E.D. Pa. 1951) ("remedies"). Cases can also be found in which exhaustion of administrative and judicial remedies was not required. See, e.g., Bruce v. Stillwell, 206 F.2d 554 (5th Cir. 1953) (administrative remedies); Curry v. Ragan, 257 F.2d 449 (5th Cir. 1958) (judicial remedies); Dyer v. Kazuhisa ABE, 138 F. Supp. 220 (D. Hawaii 1956), rev'd on other grounds, 256 F.2d 728 (9th Cir. 1958) (judicial remedies).

188 S. Ct. at 482. 
Moreover, even though a state has expressly provided as a matter of policy that there shall be no remedy for certain wrongs, the Court has held in effect that nonavailability of a state remedy is not pertinent to the question of whether the plaintiff has stated a cause of action under section 1983. Thus, a state officer is subject to civil redress in a federal court whenever his acts can be characterized as a denial of due process. He need not have intended to harm the plaintiff. It is sufficient that the deprivation of a federal right is a "natural consequence" of his acts. ${ }^{180}$

Section 1983, as interpreted in Monroe, allows the district courts to sit in judgment of the activities of officials at all levels of state and local government and to subject their activities to federal supervision. ${ }^{100}$ If a party is treated unfairly by a sheriff, county clerk, building inspector, or even by the state public welfare office, he may seek relief in a federal court. ${ }^{101}$ Under section 1983, a federal judge has the power to decide that the warden of a state prison should not censor a prisoner's mail, ${ }^{192}$ or that a hquor license should be granted to one applicant rather than to another. ${ }^{193} \mathrm{He}$ may even review the conduct of litigation in state courts,

180 See text at notes 113-23 supra.

$100 \mathrm{It}$ is imteresting to note the statement made by Justice Frankfurter a scant ten years ago in Steffanelli v. Minard, 342 U.S. 117 (1951), when, speaking for the Court, he said that $\$ 1983$ "should be construed so as to respect the proper balance between the States and the federal governments ..." and that the Civil Rights Act "[is] not to be used to centralize power so as to upset the federal system." Id. at 121. Like sentiments have also been expressed in the lower federal courts. See, e.g., Charlton v. City of Hialeah, 188 F.2d 421 (5th Cir. 1951), where Judge Holmes said that "it was not intended by the 14th Amendinent and the civil-rights statute that all matters formerly within the exclusive cognizance of the states should become matters of national concern. A construction such as that ... would find a violation of federal rights in every departure from local or state law by local or state officers." Id. at 423.

101 Federal jurisdiction under $\$ 1343(3)$ would seem to depend upon the ingenuity of counsel in casting plaintiff's injury in terms of the deprivation of a federal right. For an amazing example, see Sweeny v. Pennsylvania Dept. of Pub. Assistance Bd., 33 F. Supp. 587 (M.D. Pa. 1940), where it was held that plamtiff had stated a claim within the jurisdiction of the district court when he alleged that a denial of state welfare payntents forced him to live with his family and thus denied him liberty to hive where he pleased.

192 In McCullum v. Mayfield, 130 F. Supp. 112 (N.D. Cal. 1955), the court held that one incarcerated in a state prison states a cause of action under $\S 1983$ when he alleges that he was forced to work (clean kitchen shelves) while awaiting trial (involuntary servitude) and was refused medical care for personal imjuries suffered while in confinement (deprivation of life, liberty, and property without due process of law).

Most of the federal courts have refused to intervene in the operations of state prisons, however, and have held that suit is not authorized under $\S 1983$ for a number of reasons: (1) the federal government has no power to supervise the internal affairs of state prisons, United States v. Ragen, 237 F.2d 953 (7th Cir.), cert. denied, 353 U.S. 964 (1956) (assault and battery, interference with appeals to state tribunals); Ortega v. Ragen, 216 F.2d 561 (7th Cir. 1954) (withholding mail); (2) the defendant's actions did not constitute a denial of due process, Ortega v. Ragen, supra (withholding mail and thus preventing plaintiff from prosecuting an appeal); Whiting v. Seyfirt, 203 F.2d 773 (7th Cir. 1953) (failure of state parole authorities to act affirmatively to gain custody of plaintiff after he had been arrested in another state), or any other civil right, Chick v. Kentucky, 140 F. Supp. 418 (E.D. Ky. 1948) (failure to withdraw a warrant directing that plaintiff, when released from Texas jail, be held for Kentucky authorities as a fugitive of justice) ; (3) the prisoner is stripped of many of the rights possessed by a free person, Edgerly v. Kennelly, 215 F.2d 420 (7th Cir. 1954), cert. denied, 348 U.S. 938 (1955) (right to be a witness in his own or some other action for damages); Adams v. Ellis, 197 F.2d 483 (5th Cir. 1953) (right to be free from censorship in receipt and transmission of mail). Query whether these cases are still the law in hight of Monroe v. Pape, which seems to hold that the deprivation of a federal right by any state official gives rise to a cause of action under $\$ 1983$.

193 See, e.g., Glicker v. Michigan Liquor Control Comm'n, 160 F.2d 96 (6th Cir. 1947). 
as where it is alleged that a state judge made, or is about to make, an error of law or fact which demed, or will deny, the plaimtiff due process. ${ }^{194}$

These far-reaching effects upon the federal system should not be laid at the feet of the Supreme Court, however. The Court's interpretation of section 1983 in Monroe was a fair one; it was justified both by the clear language of that section and by the legislative history of the Third Civil Rights Act. ${ }^{195}$ The Court's holding that action under color of state law includes the illegal acts of state officials found support in its own precedents, as well as those of the lower courts. In deciding Monroe v. Pape, the Supreme Court has faithfully observed the mandate of Congress that denial of a federal right by a state official, exercising the powers of his office, shall be subject to civil redress in the district courts. If the decision causes unhappy results, it will not be because the Supreme Court has misconstrued the law. The Court has observed the letter and the spirit of the law.

\section{Thomas J. Klitgaard.}

194 Prior to Monroe, the use of $\$ \S 1343(3)$ and 1983 to supervise the conduct of litigation in state courts through the use of injunctions had met with strong resistance, not on the ground that the district courts had no jurisdiction, but on the ground that a proper respect for the federal system required them to abstain from exercising that jurisdiction. See, e.g., Steffanelli v. Minard, 342 U.S. 117 (1951) ; Stafford v. Superior Court, 272 F.2d 407 (9th Cir. 1959); Johnson v. Stone, 268 F.2d 803 (7th Cir. 1959) ; Norwood v. Parenteau, 238 F.2d 148 (8th Cir. 1955) ; Cooper v. Hutchinson, 88 F. Supp. 774 (S.D.N.J. 1950). In Cooper v. Hutchinson, supra, the court said that "if plaintiff's theory of the federal district court's imjunctive power ... were followed, fantastic results would occur, for in every state court criminal action in which the defendant raised a defense alleging deprivation of a constitutionally protected right he could institute an action that would convert a federal district court into a review forum of state court action." Id. at 783. The broad language of the Monroe case would seem to preclude an exercise of the power to abstain in such situations. See text at note 188 supra. The Supreme Court, however, has recently indicated that abstention may still be required. Pugach v. Dollinger, 29 U.S.L. WEER 4247 (U.S. Feb. 28, 1961).

195 At least one district court had suggested that the nature of plaintiff's cause of action should serve as a guide to the interpretation of $\$ 1983$ : "The theory of action should also be considered in deciding how strictly to construe the [Civil Rights] Acts. If the theory is merely one of tort then the Acts should be construed strictly but if the theory is to alter official conduct, a more hberal construction may be called for. If the action is for individual redress, then the Acts should be construed more strictly than in a broad class action which would be more in keeping with the philosophy of the Acts." Egan v. City of Aurora, 174 F. Supp. 794, 800 (N.D. Ill. 1959), afj'd, 275 F.2d 377 (7th Cir. 1960). 